\title{
What Killed the Violence Against Women Act's Civil Rights Remedy Before the Supreme Court Did?
}

\begin{abstract}
What makes for effective civil rights legislation? This paper answers that question by exploring the obscured history of the Violence Against Women Act's (VAWA) civil rights remedy. Most scholarship on the subject focuses entirely on United States v. Morrison, the Supreme Court decision that invalidated the legislation on commerce clause grounds. This paper challenges this narrative and argues that Morrison was only one of many setbacks the civil rights remedy suffered in its short history. The civil rights remedy faced a multitude of obstacles that prevented it from achieving its goal of reducing rates of violence against women by providing a sophisticated forum for victims of gender violence to seek redress and making such violence a civil rights issue. The civil rights remedy's origins were radical and based on aspirational, but unrealistic, feminist jurisprudence. Additionally, the rhetoric surrounding the legislation largely focused on its symbolic, rather than practical, function. The few lawyers who did bring VAWA claims were not benefited by a broad-based litigation campaign because women's organizations did not lead such a charge. The lawyers then faced formidable opponents who quickly challenged the statute's constitutionality. Lastly, both the lower federal courts and the press did not bolster support for the remedy. On the fiftieth anniversary of the archetypal civil rights legislation of the twentieth century, Title VII, and the twentieth anniversary of the VAWA, this paper calls for a nuanced discussion of how civil rights legislation can be designed, and used, to provoke meaningful and effective change.
\end{abstract}

\section{Table of Contents}

Introduction: Uncovering the Hidden History Of The VAWA Civil Rights Remedy..............1

Part I: The VAWA Civil Rights Remedy Was A Failure On All Possible Counts..................6

Part II: The Civil Rights Remedy Had Radical Origins...................................13 Part III: At the Moment Of Its Passage, the Civil Rights Remedy Was "Relegated to a Symbolic Means of Fighting Discrimination"....

Part IV: Only Individual Attorneys Brought Claims and A Central Organization Did Not Assist

Them Or Lead A Litigation Campaign................................................26

Part V: Opponents Immediately Challenged The Statute's Constitutionality ...................34

Part VI: The Judiciary Did Not Embrace The Civil Rights Remedy.........................38

Part VII: The Press Did Not Report On The VAWA's Successes Or Its Civil Rights Promise...46

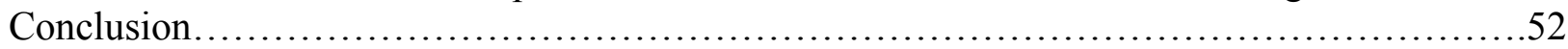

\section{Related Sources}

Alex Aleinikoff, Irasema Garza, Lynn Hecht Schafran, Victoria Nourse, Sally Goldfarb, Patricia Reuss, Hilary Shelton \& Helen Neubourne, Welcoming Remarks Panel One: Present at the Creation: Drafting and Passing the Violence Against Women Act (Vawa), 11 GeO. J. Gender \& L. 511 (2010).

Julie Goldscheid, Elusive Equality in Domestic and Sexual Violence Law Reform, 34 FLA. ST. U. L. REV. 731 (2007).

NANCY MacLEAn FreEdom IS NOT ENOUgh: The OPENING OF THE AMERICAN WORKPLACE (2006). 
Hon. Mary Schroeder, Julie Goldscheid, Judith Resnik, Fred Strebeigh, \& Martha Davis, Panel Two: The Vawa Civil Rights Provision: Shaping It, Saving It, Litigating It, Losing It, 11 GEO. J. GENDER \& L. 543 (2010).

Fred Strebeigh EQual: Women Address AMERICAN LaW (2009)

With footnotes; 22,420

\section{Word Count}

Without footnotes: 12,842 


\section{Introduction: Uncovering The Hidden History Of The VAWA Civil Rights Remedy}

On May 15, 2000, a conservative five Justice majority on the Supreme Court struck down the civil rights remedy of the Violence Against Women Act ("VAWA") in United States v. Morrison. ${ }^{1}$ The outcry from the Left was immediate, and scathing. Over the next few days, The New York Times ran editorials with glaringly critical headlines; one read "The Court Defers to a Racist Era," another "Violence Against the Constitution." These commentaries, much of the liberal press, ${ }^{4}$ and many feminist and liberal scholars, ${ }^{5}$ all blamed the Supreme Court and its recently reinvigorated commerce clause doctrine for the VAWA's demise. Although it is true that the Court delivered the final blow to the VAWA, the civil rights remedy was on its deathbed when it reached the Supreme Court.

The VAWA civil rights remedy was good law for more than five years before Morrison. The remedy created a private cause of action for victims of a "crime of violence motivated by gender" to sue their attackers for money damages in federal court. ${ }^{6}$ President Clinton signed the

\footnotetext{
${ }^{1}$ United States v. Morrison, 529 U.S. 598 (2000).

2 Jack M. Balkin, The Court Defers to a Racist Era, N.Y. TimES, May 17, 2000.

${ }^{3}$ Editorial, Violence Against the Constitution, N.Y. TIMES, May 16, 2000.

${ }^{4}$ For a discussion of the press' response to United States v. Morrison, see Part VII infra. See also Sarah F. Russell, Covering Women and Violence: Media Treatment of Vawa's Civil Rights Remedy, 9 MICH. J. GENDER \& L. 327 (2003).

${ }^{5}$ For example of scholarship critical of the Supreme Court's decision see Catharine A. MacKinnon, Disputing Male Sovereignty: On United States v. Morrison, 114 HARV. L. REV. 135 (2000); Sally F. Goldfarb, "No Civilized System of Justice": The Fate of the Violence Against Women Act, 102 W. VA. L. REV. 499 (2000); Sally F. Goldfarb, The Supreme Court, the Violence Against Women Act, and the Use and Abuse of Federalism, 71 FORDHAM L. REV. 57 (2002); Julie Goldscheid, United States v. Morrison and the Civil Rights Remedy of the Violence Against Women Act: A Civil Rights Law Struck Down in the Name of Federalism, 86 CoRNELL L. REV. 109 (2000); Julie Goldscheid, The Civil Rights Remedy of the 1994 Violence Against Women Act: Struck Down but Not Ruled Out, 39 Fam. L.Q. 157, 159 (2005). Jennifer R. Hagan, Can We Lose the Battle and Still Win the War?: The Fight Against Domestic Violence After the Death of Title III of the Violence Against Women Act, 50 DEPAUL L. REV. 919 (2001); Angie Perone, Unchain My Heart: Slavery As A Defense to the Dismantling of the Violence Against Women Act, 17 Hastings Women's L.J. 115 (2006); Melissa Irr, United States v. Morrison; an Analysis of the Diminished Effect of Congressional Findings in Commerce Clause Jurisprudence and A Criticism of the Abandonment of the Rational Basis Test, 62 U. PITT. L. REV. 815, 816 (2001); Ana Maria Merico-Stephen, United States v. Morrison and the Emperor's New Clothes, 27 J.C. \& U.L. 735 (2001); Alberto B. Lopez, Forty Yeas and Five Nays-the Nays Have It: Morrison's Blurred Political Accountability and the Defeat of the Civil Rights Provision of the Violence Against Women Act, 69 GEO. WASH. L. REV. 251 (2001).

${ }^{6} 42$ U.S.C $\$ 13981$ (1994). The entire text of the statute is in Appendix I.
} 
VAWA legislation into law on September 13, 1994, which was part of the broader Violent Crime Control and Law Enforcement Act of 1994. ${ }^{7}$ The VAWA legislation represented the culmination of several years of advocacy on Capitol Hill. ${ }^{8}$ Senator Joe Biden was the law's champion and most high-profile supporter. In addition to creating the civil rights remedy, the VAWA provided 1.62 billion federal dollars to a wide-array of state and federal agencies to combat violence against women. ${ }^{9}$ According to Biden and supporters, the civil rights remedy was the "single most important part" of the VAWA. ${ }^{10}$

The Supreme Court struck down the civil rights remedy in May 2000. ${ }^{11}$ The victim of a gang rape at Virginia Tech, Christy Brzonkala, sued her two attackers under the civil rights remedy. ${ }^{12}$ The men argued as a defense that the law was an improper exercise of Congressional power. ${ }^{13}$ The Court sided with the defendants and held that Congress lacked the authority, under

\footnotetext{
7 “The History of The Violence Against Women Act," U.S. Department of Justice, Office of Violence Against Women, available at http://www.ovw.usdoj.gov/docs/history-vawa.pdf.

${ }^{8}$ Senator Joe Biden assigned a member of the Senate Judiciary Committee to brainstorm solutions to the problem of violence against women in the spring of 1990. FRED STREBEIGH, EQUAL: WOMEN ADDRESS AMERICAN LAW 309 (2009). The first version of the legislation was introduced by Biden on June 19, 1990. Id. at 338 (citing Victoria F. Nourse, Where Violence, Relationship, and Equality Meet: The Violence Against Women Act's Civil Rights Remedy, 11 Wis. WOMEN'S L.J. 1, 7 (1996).

${ }^{9}$ The Violence Against Women Act brought "unprecedented recognition and resources to the issue [of violence against women]. Among its other accomplishments, the 1994 legislation made it a federal crime to cross state lines in order to commit domestic violence or to violate a protection order. It required states to give full faith and credit to protection orders issued by other states. It authorized federal grant to increase the effectiveness of police, prosecutors, judges, and victim services agencies. It provided funding for a national toll-free domestic violence hot line. It increased federal financial support for battered women's shelters. It reformed immigration law to help immigrant workers escape their abusers without being forced to leave the country. It amended the Federal Rules of Evidence to extend rape shield protection to civil as well as criminal cases. It provided federal leadership for efforts to expand research and record-keeping on violence against women." Alex Aleinikoff, Irasema Garza, Lynn Hecht Schafran, Victoria Nourse, Sally Goldfarb, Patricia Reuss, Hilary Shelton \& Helen Neubourne, Welcoming Remarks Panel One: Present at the Creation: Drafting and Passing the Violence Against Women Act (Vawa), 11 GEO. J. GENDER \& L. 511, 522 (2010).

${ }^{10}$ The Implementation of the Violence Against Women Act Provisions of the Violent Crime Control and Law Enforcement Act (Public Law 103-322): Hearing Before the S. Committee on the Judiciary, 103rd Congress (1994) (Statement of Joseph R. Biden, Chairman, S. Committee on Judiciary).

${ }^{11}$ Morrison, 529 U.S. 598.

${ }^{12}$ Id. at 601-03; For a more detailed discussion of the facts see Brzonkala v. Virginia Polytechnic Inst. \& State Univ., 169 F.3d 820, 906-07 (4th Cir. 1999) (Motz, dissenting), aff'd sub nom. United States v. Morrison, 529 U.S. 598, 120 S. Ct. 1740,146 L. Ed. 2 d 658 (2000).

${ }^{13}$ Id.
} 
either the commerce clause or the Fourteenth Amendment's equal protection and enforcement clauses, to create such a provision. ${ }^{14}$

The public imagination, and much of the scholarship, has been captured by this Supreme Court decision. Judicial activism, federalism, and commerce clause jurisprudence are the central themes of the narrative that is typically told; depending on the political affiliation of the storyteller, it is either a heroic victory for those opposed to a large federal government, ${ }^{15}$ or a devastating loss for supporters of women's rights. The latter account places blame entirely on the Supreme Court, particularly Chief Justice Rehnquist, who spoke out against the civil rights remedy prior to VAWA's passage. ${ }^{16}$ Most leftist and feminist scholars, particularly those involved in the creation and passage of the VAWA, take this position. ${ }^{17}$ The origins of the civil rights remedy, its legislative history, and the five plus years when it was good law, have largely been ignored. ${ }^{18}$

\footnotetext{
${ }^{14} I d$. at $613,627$.

${ }^{15}$ For an example of scholarship in support of the Supreme Court's ruling, see Yes, Virginia (Tech), Our Government Is One of Limited Powers: United States v. Morrison, 120 S. Ct. 1740 (2000), 24 HARV. J.L. \& PUB. POL'Y 895 (2001); Lamar F. Jost, Constitutional Law-the Commerce Clause in the New Millennium: Enumeration Still Presupposes Something Not Enumerated. United States v. Morrison, 120 S. Ct. 1740 (2000)., 1 WYO. L. REV. 195 (2001); Jason Everett Goldberg, Substantial Activity and Non-Economic Commerce: Toward A New Theory of the Commerce Clause, 9 J.L. \& POL'Y 563 (2001). Conservative press also wrote in support of the Supreme Court's ruling. See e.g., Andrea Neal, Enough of Congress Meddling, InDIANAPOLIS STAR, May 25, 2000, at A16 ("Congress should know better than to federalize state crimes"); Lee Anderson, Rape: Terrible Crime, Correct Ruling, Chattanooga Free Press, May 17, 2000, at B7 ("Not everything should be made into a "federal case'"); Bradley R. Gitz, Constitutional Abuse, ARK. DemOCRAT-GazeTte, June 2, 2000 ("the court acted to preserve the authority of state and local governments in the crucial area of law enforcement"). These newspaper articles were first collected by Sarah F. Russell, see Russell, supra note 4 at 380-92.

${ }^{16}$ For example, Fred Strebeigh's account of the origins, passage, and demise of the VAWA civil rights remedy paints Chief Justice as the enemy, who actively campaigned against the proposed VAWA, plotted a plan to take it down after passage, and ultimately succeeded in Morrison. See Strebeigh, EQUAL: WOMEN ADDRESS AMERICAN LAW, supra note 8. Catherine MacKinnon's more sophisticated account of Morrison as a victory for the "social institution of male dominance" nonetheless still focuses heavily on the Court's role in invalidating the VAWA: "In Morrison, the Court revived and deployed against women the odious 'states' rights' doctrine, the principal legal argument for the maintenance of slavery that was used to deny equality rights on racial grounds well into this century." MacKinnon, Disputing Male Sovereignty, supra note 5 at 136-37.

${ }^{17}$ For a collection of the articles in this vein, see supra note 5.

${ }^{18}$ A handful of scholarship discusses the civil rights remedy's legislative history, most of this has been written by those intimately involved with the creation. See Nourse, supra note 8; Alex Aleinikoff, Irasema Garza, Lynn Hecht Schafran, Victoria Nourse, Sally Goldfarb, Patricia Reuss, Hilary Shelton \&Helen Neubourne supra note 9. Other
} 
This paper canvasses these sources and makes an important observation: when the civil rights remedy arrived at the Court in Morrison, it was not a vibrant civil rights statute that was being used to effectuate change across the country. Only a few cases had been brought under the remedy. ${ }^{19}$ Those cases that were brought faced immense challenges. And they provided little, if any, relief. The remedy also failed to reframe the dialogue about violence against women by cementing in the public consciousness the idea that violence against women violated a civil right. ${ }^{20}$ The VAWA civil rights remedy was a far cry from the archetypal civil rights legislation of the modern era: Title VII of the Civil Rights Act of 1964. This legislation was used broadly in the years following its passage to remedy individual acts of employment discrimination, reframe the public's conception of civil rights, and fundamentally change the character of the American workplace. $^{21}$

This paper asks why the VAWA civil rights remedy was so unsuccessful. ${ }^{22}$ A detailed study of the civil rights remedy's legislative history, court opinions from cases filed under the

scholars have discussed the small quantity of litigation brought under the VAWA prior to Morrison and attempted to explain it, for a discussion of this literature, see infra note 22, 128.

${ }^{19}$ This paper has located 59 unpublished and published opinions that contain a claim under the VAWA. For a discussion of this total and its implications, see infra Part I.

${ }^{20}$ For a discussion of the civil rights remedy's conceptual failure, see infra Part I; see also infra Part VI, VII.

${ }^{21}$ See infra, Part I. See also NANCY MaCLEAN FREEDOM IS NOT ENOUGH: THE OPENING OF THE AMERICAN WORKPLACE (2006).

${ }^{22}$ Julie Goldschied, who argued Morrison on behalf of the The National Organization for Women Legal Defense Fund ("NOW LDF"), is one of the few scholars who have considered this question. See Julie Goldscheid, Elusive Equality in Domestic and Sexual Violence Law Reform, 34 FLA. ST. U. L. REV. 731 (2007). See also Christopher James Regen, A Whole Lot of Nothing Going On: The Civil Rights Remedy' of the Violence Against Women Act, 75 NotRE DAME L. ReV. 797 (1999) discussed infra note 128. She suggests that the VAWA civil rights remedy did not produce a significant volume of litigation because of the fundamental limitations of civil remedies. Id. According to Goldscheid, plaintiffs did not bring claims in court because they were not interested in the procedurea civil action, and the remedy - monetary compensation, which the VAWA could provide. Id. A victim of gender violence, "rationally may choose not to reengage with the batterer through tort or other civil litigation out of a desire to limit, rather than increase, her contact with him. Id. at 769. Litigation could carry significant risks - a victim might "reasonably fear" that it would be employed as a "further device for perpetuating a pattern of coercion and control over her." Id. Additionally, a victim of gender-violence may not desire financial compensation from the perpetrator but instead want remedies a civil suit cannot provide, including "financial assistance (from sources other than the batterer), jobs, childcare, immigration assistance, and legal representation [for other court proceedings like child custody and divorce]." Id. at 770 . This paper agrees, in part, with the claim that all victims of gendermotivated violence may not have desired civil litigation, but argues that this is a vastly incomplete explanation for 
law when it existed, the press coverage of the remedy, and existing secondary source literature discussing the legislation all suggest that the VAWA civil rights remedy faced a host of structural problems from the outset. These systemic problems made success highly unlikely, even without the constitutional ruling. First, the civil rights remedy's inception was radical. The legislation was based on the writings of the most extreme feminist legal thinkers, which placed it far outside the mainstream and made widespread public embrace unlikely at best. ${ }^{23}$ Second, at the moment of the legislation's passage, its symbolic value was continually emphasized over its practical purpose. ${ }^{24}$ This overshadowing proved problematic and eventually proved true - the visionary legislation was used only to send a message, rather than make real change.

Once the civil rights remedy was in place, it faced even greater obstacles. Most lawyers who brought claims were in fact individual practitioners, operating with neither support nor significant resources. ${ }^{25}$ Feminist and women's groups failed to use their more considerable resources to support the remedy; one prominent group did not support the remedy at all. ${ }^{26}$ When

the VAWA's failure. It is true that the "proportion of rape survivors who file civil suits [under state law tort statutes or state civil rights statutes] is alarmingly low.” Tom Liniger, Is it Wrong to Sue for Rape, 57 DuKE L.J. 1557, 1615 (2008). One expert suggests less than ten percent of survivors bring claims, $i d$. (internal citations omitted) and this may be, in part, because of the reasons noted above-some women may prefer not to bring suit against their attacker because of a desire to not face him in court, because he is still their spouse or partner, or to avoid the emotional costs of litigation. Despite these considerations, however, research also shows that, since the 1970s, civil litigation for rape has "swelled." Id. at 1568. "The rate of such litigation increased in the 1980s, the trend accelerated in the 1990 s, and the number of lawsuits grew 'exponentially' beginning in 2000." Id. This surge is "remarkable considering that the frequency of rapes appears to have decreased during the period in which the rate of civil litigation has risen." Id. Additionally, although rates of violence against women have declined, they are still very high, and even if a small percentage of women brought claims, the number of cases should have been far more than the number that occurred under the VAWA civil rights remedy. See discussion infra note 128. Lack of victim enthusiasm for suits was only a small part of the explanation for the lack of litigation under the VAWA civil rights remedy.

${ }^{23}$ The civil rights remedy was based primarily on the writings of Robin West and Catherine A. MacKinnon. See infra Part II.

${ }^{24}$ Senator Joe Biden frequently spoke about the VAWA's symbolic function and the message the civil rights remedy was intended to send. See infra Part III.

${ }^{25}$ Research has located only three "repeat players," lawyers or firms who were involved in bringing more than one original case. (NOW LDF was involved in more than one case as an intervener and/or amicus). For a discussion of these repeat players and their limitations, see infra, Part IV.

${ }^{26}$ NOW LDF had some involvement in the litigation but did not bring cases. The ACLU as a whole, including the Women's Rights Project, did not support the remedy. See infra Part IV. 
cases were brought, the opposition - conservative groups and enterprising lawyers that argued the legislation was unconstitutional—quickly rebutted them. ${ }^{27}$ Judges that adjudicated the few existing claims often did not conceptualize the remedy as a civil rights statute and read it narrowly, indicating that much of the judiciary did not embrace the statute in the years before Morrison. ${ }^{28}$ Lastly, the press did not report on the VAWA's successes and did not engage in a dialogue about its function as a civil rights statute, limiting public knowledge and discourse about the goals of the legislation and its work in practice. ${ }^{29}$ Together, these challenges severely crippled the civil rights remedy the Supreme Court's decision. This paper will analyze these obstacles in detail. Doing so will uncover the many forces operating at different levels_ public and private, conceptual and practical, legislative and judicial, social movement and media - that must come together in tandem for civil rights legislation to be both meaningful and effective. By highlighting the multitude of factors that prevented success, this paper will prove that simple passage of civil rights legislation is not sufficient to initiate change, and that judicial invalidation of that legislation is not the only way to bar success.

\section{Part I: The VAWA Civil Rights Remedy Was A Failure On All Possible Counts}

"The success" of civil rights legislation is tricky to determine. First, the measuring stick used to evaluate success must be decided. One could analyze the success of the VAWA civil rights remedy based on the goals of those involved in its conception and passage. These advocates had two primary purposes with the legislation: first, providing victims of genderviolence a forum and method to seek redress, and second, sending a symbolic message that

\footnotetext{
${ }^{27}$ For a discussion of the first constitutional challenges to the civil rights remedy, see infra Part V.

${ }^{28}$ For a discussion of the judicial response to the VAWA, see infra part VI.

${ }^{29}$ For a discussion of the press' coverage of the VAWA, see infra part VII.
} 
violence against women violated a civil right. ${ }^{30}$ Another way to measure the success of the civil rights remedy is to determine if it actually fixed the problem it was devised to solve. That is, did it reduce the amount of violence against women in our society? Whichever measuring stick is chosen, the conclusion is clear: the civil rights remedy was a failure.

Few victims sought redress under the remedy and received compensation for their injuries. Litigation under the VAWA was infrequent and insignificant in impact. Research reveals that only fifty-nine opinions ${ }^{31}$ discuss a VAWA civil rights remedy claim. ${ }^{32}$ The VAWA intended for federal court to be the forum for claims, but also provided joint jurisdiction in the states. ${ }^{33}$ Fifty-one of these cases were filed in federal court and eight in state court. This total includes both published opinions - those that were selected to be printed in the Federal Reporter or Federal Supplement-and unpublished opinions - those that Westlaw or Lexis have made available online with the appropriate designation. Ten of the fifty-nine were unpublished. Federal district courts decided the majority of these cases. ${ }^{34}$

\footnotetext{
${ }^{30}$ The two goals of the civil rights remedy articulated by advocates are detail in Part III infra.

${ }^{31}$ This estimate of the number of VAWA claims brought is corroborated by other sources. Julie Goldschied stated that by the time of Morrison, "[b]etween fifty and sixty lower court decisions had addressed the civil rights remedy and virtually all upheld its constitutionality." Hon. Mary Schroeder, Julie Goldscheid, Judith Resnik, Fred Strebeigh, \& Martha Davis, Panel Two: The Vawa Civil Rights Provision: Shaping It, Saving It, Litigating It, Losing It, 11 GEO. J. GENDER \& L. 543, 548 (2010). See also Regen, supra note 22 at 816 (collecting forty cases as of December 1999).

${ }^{32}$ A full list of the opinions, including their citations, is available in Appendix II.

3342 U.S.C $\$ 13981$.

${ }^{34}$ Of the fifty-nine opinions, five of them, including the Morrison litigation, were appealed to federal appellate courts and resulted in an opinion at that level. Three of these also produced a published opinion at the district level. Brzonkala v. Virginia Polytechnic \& State Univ., 935 F. Supp. 779 (W.D. Va. 1996) rev'd sub nom. Brzonkala v. Virginia Polytechnic Inst. \& State Univ., 132 F.3d 949 (4th Cir. 1997) on reh'g en banc, 169 F.3d 820 (4th Cir. 1999) aff'd sub nom. United States v. Morrison, 529 U.S. 598, 120 S. Ct. 1740, 146 L. Ed. 2d 658 (2000) and aff'd sub nom. Brzonkala v. Virginia Polytechnic Inst. \& State Univ., 169 F.3d 820 (4th Cir. 1999) aff'd sub nom. United States v. Morrison, 529 U.S. 598, 120 S. Ct. 1740, 146 L. Ed. 2d 658 (2000); Doe v. Mercer, 31 F. Supp. 2d 208 (D. Mass. 1998) vacated sub nom. Doe v. Walker, 193 F.3d 42 (1st Cir. 1999); Doe v. Hartz, 970 F. Supp. 1375 (N.D. Iowa 1997) rev'd in part, vacated in part, 134 F.3d 1339 (8th Cir. 1998). For the purposes of this calculation, even though the three cases produced more than one opinion (a district and an appellate one, and in Morrison, a Supreme Court decision), these are counted as only one "case" in the total fifty-nine count. Two cases resulted in a published opinion at the federal appellate level and the district level did not produce an opinion. Gross v. Weber, $186 \mathrm{~F}$. 3d 1089 ( $8^{\text {th }}$ Cir. 1999); Schwenk v. Hartford, 204 F.3d 1187 (9th Cir.2000).
} 
Although published opinions may not accurately reflect the total number of cases filed, it is possible to estimate the total number brought based on the published count. Empirical studies for other types of litigation have attempted to predict the ratio of total cases brought to written opinions produced. These studies have found that between five ${ }^{35}$ and twenty percent ${ }^{36}$ of all cases result in a published opinion. This suggests a range of 295 to 1,180 cases, total.

Additionally, there is reason to believe that a case containing a VAWA claim would be more likely to result in a published or unpublished opinion, indicating that even these small estimates may be high. Scholars have found that cases brought under federal statutes, including civil rights statutes, are more likely to produce published opinions than other types of claims. ${ }^{37}$ Furthermore, cases that deal with a new issue or "break novel legal ground" are more likely to produce an opinion. ${ }^{38}$ New scholarship, based on a behavioral theory of judging, argues that judges write opinions most when a case is likely to be appealed, reviewed, and potentially reversed.$^{39}$ Given that most of the judges writing the opinions were adjudicating it for the first time, and many of the opinions dealt with the constitutionality of a federal statute, which became a question that divided the lower federal courts, it seems likely that a larger portion of VAWA cases produced a written opinion.

As a result, the fifty-nine published opinions, and the projections of how many cases these resulted from (between 295 and 1,180, with a number closer to 295 far more likely), are at least a useful proxy for the amount of VAWA litigation that occurred. This research ${ }^{40}$ points to a

\footnotetext{
35 Susan M. Olson, Studying Federal District Courts Through Published Cases: A Research Note, 15 JuST. Sys. J. 782, 790 (1992).

${ }^{36}$ Peter Siegelman and John J. Donohue III, Studying the Iceberg from Its Tip: A Comparison of Published and Unpublished Employment Discrimination Cases, 24 LAW \& SOC'Y REV. 1133, 1141 (1990)).

${ }^{37}$ Olson, supra note 32 at 790 tbl.1

${ }^{38}$ Siegleman and Donohue, supra note 33 at 1149.

${ }^{39}$ David A. Hoffman et. al., Docketology, District Courts, and Doctrine, 85 WASH. U.L. REV. 681,704 (2007).

${ }^{40}$ Further evidence of the dearth of claims brought under the VAWA was provided by a search of the federal court dockets on Bloomberg Law. A search for "violence against women act" during the period in which VAWA was
} 
key conclusion: the civil rights remedy of the VAWA did not produce many cases, which meant that the VAWA did not bring relief to significant numbers of individual victims of gendermotivated violence.

Second, the VAWA did not change the conception of violence against women and solidify in the public consciousness that such acts constituted civil rights violations. Indeed, during the time when the VAWA was good law, both the judiciary ${ }^{41}$ and the press ${ }^{42}$ did not fully embrace the concept that violence against women violated a civil right. The fact that Congress had made it such, did not solidify this idea in the public's eye, neither before nor after the Morrison ruling. ${ }^{43}$ Recently, a conference at the University of Virginia gathered over 250 representatives from colleges and universities across the country to discuss the epidemic of rape and sexual assaults on college campuses and indicated these problems are not commonly perceived of as civil rights violations. When the Department of Education's Civil Rights Division's chief officer declared at this event that protection from sexual assault on campus was a civil right, ${ }^{44}$ even in a room full of people actively interested in this issue, the claim was received as a revelation. And, the speaker was only discussing sexual assault on campus, not in

good law located seventy-two additional cases in which a VAWA claim was filed, bringing the total cases to 131 . These additional cases did not result in a published opinion or an opinion that was harvested by WestLaw or LexisNexis. This could be explained by a variety of circumstances, for example if the case was settled early in the litigation, or if the judge ruled from the bench without issuing a formal written opinion. The few cases found in the search, which touches all federal district court dockets, is further evidence that a very small amount of litigation occurred under the VAWA. Because this search is fallible (it did not locate all fifty-nine cases in which an opinion resulted) and because the written opinions provide factual and legal information not available on a docket, the fiftynine opinions will serve as the analytical foundation for this paper.

${ }^{41}$ For a discussion of the judiciary's response to the civil rights remedy see infra Part VI.

${ }^{42}$ For a discussion of the press' response to the civil rights remedy see infra VII.

${ }^{43}$ This position is directly opposed to the view of Sally Goldfarb, a NOW LDF activist who helped secure passage of the civil rights remedy. At a commemoration celebrating the fifteenth anniversary of the VAWA, Goldfarb stated: "But even after the civil rights provision was stripped of the force of law, it continues to resonate today. It has changed the terms of the debate. The idea that women have a right to be free from violence directed at them because of their gender, which was once a novel concept, is now a mainstream, commonplace idea." Alex Aleinikoff, Irasema Garza, Lynn Hecht Schafran, Victoria Nourse, Sally Goldfarb, Patricia Reuss, Hilary Shelton \& Helen Neubourne supra note 9 at 522 .

${ }^{44}$ Event, "Dialogue at UVA: Sexual Misconduct Among College Students," University of Virginia, February 10, 2014. 
other realms. It appears that most of the populace does not recognize sexual assaults and gender violence as a civil rights issue today.

Third, the VAWA civil rights remedy did not significantly reduce the amount of violence against women in the United States. Although there is evidence that rates of violence against women have fallen since $1994,{ }^{45}$ the rates are still alarmingly high. It is estimated by the Center for Injury Prevention and Control that nearly one in five women has been raped in the United States, and one in four women has experienced severe physical violence by an intimate partner (e.g. "hit with a fist or something hard, beaten, slammed against something). ${ }^{46}$ Estimates of the precise number of rapes and intimate partner violence per year vary, but they all point to the same conclusion: this is still an enormous problem in the United States today. The National Crime Victimization Survey completed by the Department of Justice estimated that there were over 346,000 rapes/sexual assaults in the United States in 2012, about the same as in $2003 .{ }^{47}$ Other studies have found larger numbers: one estimated that in 2007, over one million women had been raped. ${ }^{48}$ It is clear that the civil rights remedy did not fix this problem.

All of these measures stand in stark contrast to the most successful civil rights legislation of the twentieth century, Title VII. Title VII achieved all three of these goals: creating a forum and opportunity for redress for a significant number of plaintiffs, solidifying the concept that employment discrimination was a federal civil rights issue, and significantly reducing the

\footnotetext{
${ }^{45}$ One study indicates that between 1993 and 2010, the rate of intimate partner violence fell sixty-seven percent. See White House VAWA Factsheet, available at http://www.whitehouse.gov/sites/default/files/docs/vawa_factsheet.pdf. Another suggests that number of sexual assaults against women over age twelve fell by sixty-four percent from 1995 to 2005. See United States Department of Justice Special Report: Female Victims of Sexual Violence 1994-2010, available at http://bjs.gov/content/pub/pdf/fvsv9410.pdf. However, most of these government documents attribute this downward trend to the funding portions of the legislation, rather than the civil rights remedy. See id. ${ }^{46}$ National Center for Injury Prevention and Control, Division of Violence Prevention, "The National Intimate Partner and Sexual Violence Survey: 2010 Summary Report," available at http://www.cdc.gov/violenceprevention/pdf/nisvs_report2010-a.pdf.

${ }^{47}$ Department of Justice, Bureau of Justice Statistics, "Criminal Victimization 2012," available at http://www.bjs.gov/content/pub/pdf/cv12.pdf.

${ }^{48}$ Kilpatrick et. al, "Drug-facilitated, Incapacitated, and Forcible Rape: A National Study," 2007, available at https://www.ncjrs.gov/pdffiles1/nij/grants/219181.pdf
} 
practice of employment discrimination. The number of claims brought immediately after Title VII was passed is remarkable in contrast to the claims brought in the first years of the VAWA. In the first year after the passage of Title VII, the Equal Employment Opportunities Commission received 9,000 complaints from aggrieved workers seeking redress. ${ }^{49}$ Seven years later, in 1975, 77,000 complaints were received.$^{50}$ Additionally, class-action lawsuits, filed in federal courts after EEOC review during the same period were plentiful—over $1,200^{51}$ were brought between 1965 and $1972 . .^{52}$

Title VII also reframed the dialogue about civil rights; it sparked a "veritable revolution" in how Americans "think[] about race and gender and work." ${ }^{53}$ African Americans struggle against economic exclusion and their victory with Title VII altered the conception of equality in America. Once African Americans began successfully "countering the established ideology that what employers did with their property was their own business and that what happened to black workers was their own doing," they focused on ending "the most potent barrier to black access . . . [not] malicious, intentional discrimination [but] ... a habitual employer preference for whites: the unthinking assumptions bred by long acceptance of exclusion. ${ }^{״ 4}$ This shifted what people

\footnotetext{
${ }^{49}$ MacLean, supra note 20 at 76 (citing Richard B. Freeman, "Black Economic Progress after 1964: Who has Gained and Why?" in STUDiES IN LABOR MARKETS, ed. Sherwin Rose (Chicago, 1981), 269).

$50 \mathrm{Id}$.

${ }^{51} I d$. at 86 .

${ }^{52}$ Although there is evidence that the focus of litigation under Title VII has shifted significantly since the 1960s, see John J. Donohue III Peter Siegelman, The Changing Nature of Employment Discrimination Litigation, 43 Stan. L. Rev. 983 (1991); Kevin M. Clermont \& Stewart J. Schwab, How Employment Discrimination Plaintiffs Fare in Federal Court, 1 J. Empirical Legal Stud. 429 (2004); Kevin M. Clermont \& Stewart J. Schwab, Employment Discrimination Plaintiffs in Federal Court: From Bad to Worse, 3 Harv. L. \& Pol'y Rev. 103 (2009), the civil rights law continues to actively be used in the federal courts. During the same five and a half year period that the VAWA civil rights remedy was good law in the 1990s, 9,875 opinions citing Title VII were located on a WestLaw. (Based on a WestLaw search for 42 USC 2000(e)). According to the United States Courts, between 1995 and 2000, approximately 100,000 employment suits were filed. See Administrative Office of US Courts, Judicial Facts and Figures 2005, U.S. District Courts Civil Cases Filed, available at http://www.uscourts.gov/Statistics/JudicialFactsAndFigures/JudicialFactsAndFigures2005.aspx (stating that in $1995,19,059$ suits were filed, in 2000, 21,032).

${ }_{54}^{53}$ MacLean, supra note 20 at 2.

${ }^{54} I d$. at 54 .
} 
believed was required by American's republican heritage and Constitution: equality "not just as a right and a theory," but as a "fact and result." ${ }^{\text {" In }}$ In sum, "legal change invited social action, which itself altered ideas and institutions." ${ }^{96}$

Third, the significant quantity of litigation brought under Title VII produced tangible and meaningful results. According to historian Nancy MacLean, "a profound alteration has occurred in American workplaces over the last fifty years." ${ }^{57}$ MacLean attributes this "veritable revolution" ${ }^{\text {58 }}$ largely to the passage of Title VII. As Africans-Americans began "challenging economic exclusion as a denial of full and fair citizenship" they, "began a process that shifted the very axis of politics in the United States." ${ }^{59}$ Although in 1950 it was "rare to see black professionals, or even skilled blue-collar or white-collar workers... today such sights are commonplace. ${ }^{\prime 60}$ This change is "deeper and wider" than a few prominent men and women of color, and has touched almost all "occupational categories," and included other previously excluded groups including women, Mexican-Americans, Asian-Americans and people with disabilities ${ }^{61}$ Forty years ago it was uncommon to see "a black male anchor on the evening news, board a bus with a white woman at the wheel, [or] speak with a Latina office manager" but now, such sightings are an everyday occurrence.$^{62}$ This is largely a result of Title VII. ${ }^{63}$

\footnotetext{
${ }^{55} I d$. at 5 (citing "Remarks of the President at Howard University, Washington, D.C.: To Fulfill These Rights," June 4, 1965, box 172, EX SP-93, WHCF, LBIJ).

${ }^{56} I d$. at 4.

${ }_{57}^{57} \mathrm{Id}$. at 2.

${ }_{58}^{58} I d$.

${ }^{59} \mathrm{Id}$. at 4 .

${ }^{60} I d$. at 2.

${ }^{61} I d$.

${ }^{62} I d$.

${ }^{63}$ Although Title VII significantly opened the workplace and improved the economic situation of many minorities, this paper acknowledges that the legislation had limits, and did not achieve full equality or entirely eliminate all discrimination. See id. at 300-47. See also Judith Stein, Running SteEl, RunNing AMERICA: RACE, ECONOMIC Policy and the DeCline of Liberalism. $C f$. Gavin Wright, Sharing the Prize: The Economics of the Civil Rights REVOLUTION (2013) (cataloguing the significant gains that African Americans made economically as a result of the Civil Rights Movement).
} 
This paper will now turn to the multitude of challenges that the VAWA faced, long before Morrison, which so distinguished it from Title VII, and that made widespread use and success unlikely. These obstacles came in two forms: those inherent to the remedy's design, and those external to it, which impeded the remedy shortly after its passage.

\section{Part II: The Civil Rights Remedy Had Radical Origins}

Victoria Nourse, ${ }^{64}$ an attorney on the Senate Judiciary Committee appointed by Biden to research how a judicial remedy could help end violence against women, first imagined the civil rights remedy. Nourse relied on three $\operatorname{sources}^{65}$ to draft the solution she ultimately landed on: a private cause of action for victims of gender-motivated violence. An examination of these sources reveals that Nourse's solution was radical, and based on non-mainstream ideas that had not been embraced, by either the government or the public. Indeed, the passage of the VAWA civil rights remedy was far from likely and was a major victory for left-wing thinkers and feminists. ${ }^{66}$ However, these radical origins proved troublesome in practice. The civil rights remedy was aspirational, but not something that achieved mainstream appeal for practitioners ${ }^{67}$ or support from the judiciary ${ }^{68}$ or press. $^{69}$

\footnotetext{
${ }^{64}$ Nourse graduated from Boalt Hall six years prior. Before accepting a position with the Senate, she completed a clerkship for a federal judge, worked for New York law firm Paul Weiss, and held a position with the Department of Justice. Strebeigh, supra note 8 at 309-- 11. Before Biden's assignment, she had not significantly studied feminist legal theory or women's issues. Id. at 310.

${ }^{65}$ Nourse relied on one Reconstruction civil rights statute (42 U.S.C. $1985 \S$ (3) and the writings of Robin West and Catharine MacKinnon to create the civil rights remedy. See infra.

${ }^{66}$ For discussions of the legislative history of the civil rights remedy that highlight the difficulty of passage, see Nourse, Where Violence, Relationship, and Equality Meet, supra note 8; Sally Goldfarb, The Civil Rights Remedy of the Violence Against Women Act: Legislative History, Policy Implications \& Litigation Strategy, A Panel Discussion Sponsored by the Association of the Bar of the City of New York, September 14, 4 J.L. \& POL'Y 391 (1996). See also Renee L. Jarusinsky, Gender Difference in Perceiving Violence and Its Implication for the Vawa's Civil Rights Remedy, 27 FORDHAM URB. L.J. 965, 968-71 (2000); Alex Aleinikoff, Irasema Garza, Lynn Hecht Schafran, Victoria Nourse, Sally Goldfarb, Patricia Reuss, Hilary Shelton \& Helen Neubourne, Panel One: Present at the Creation: Drafting and Passing the Violence Against Women Act (Vawa), supra note 9.

${ }^{67}$ For a discussion of the first practitioners to use the VAWA civil rights remedy, see infra Part IV.

${ }^{68}$ For a discussion of the judiciary's response to the statute see infra Part VI.

${ }^{69}$ For a discussion of the press' response to the statute see infra Part VII.
} 
The first source relied upon by Nourse was one of the few Reconstruction statutes to survive the post-bellum Supreme Court-42 U.S.C. $\$ 1985$ (3). Passed as part of the Civil Rights Act of 1871, the statute allowed injured victims of a conspiracy "for the purpose of depriving, either directly or indirectly, any person or class of persons of the equal protection of the laws, or of the equal privileges and immunities of the laws" to sue their attackers for monetary damages in federal court. ${ }^{70}$ The law aimed to protect freed blacks against violence and intimidation by the Ku Klux Klan. In 1971, the Supreme Court held in Griffin v. Breckenridge that $§ 1985$ (3) did not contain a state action requirement and thus could be used against private individuals. ${ }^{71}$

Second, the writings of Robin West, which drew a parallel between this civil rights act and modern violence against women, educated Nourse. In her initial research, Nourse read an article in the Florida Law Review about a study of Florida courts finding "irrefutably that gender-based biases are distorting the justice system and that the victims of the distortion are overwhelmingly women." ${ }^{, 72}$ At a talk commenting on this research that was reviewed by Nourse, West focused on the persistence of the "marital rape exception," or in other words the "the law's ancient rule that a man is exempt from being charged with raping his wife." ${ }^{73}$ Nourse also learned from the subsequent article published by West, ${ }^{74}$ that as of 1990 , a "majority of states, by a wide variety of legal means ... allowed husbands to, in effect, rape wives." ${ }^{75}$ Many states had

\footnotetext{
${ }^{70} 42$ U.S.C. $\S 1985$ (3) (2006).

${ }^{71}$ Griffin v. Breckenridge, 403 U.S. 8 (1971).

72 Strebeigh, supra note 8 at 328 (citing Lynn Hecht Schafran, Gender and Justice: Florida and the Nation, 42 FLA. L. R. 181 (1990))

${ }^{73}$ Id. (citing Jill Elaine Hasday, Contest and Consent: A Legal History of Marital Rape, 88 CAL. L. REV. 1373,1329 (2003)

${ }^{74}$ Robin West, Equality Theory, Marital Rape, and the Promise of the Fourteenth Amendment, 42 FLA. L. REV. 45 (1990).

${ }^{75}$ Strebeigh, supra note 8 at 330.
} 
expanded the exception to cohabitants, a type of "live in rape protection;" one state even extended an exception to "voluntary social companions."76

In addition to educating Nourse about the judicial and legal bias permeating many states, West's article made a crucial point that uncovered for Nourse a potential solution to the problem at hand. West argued that the marital rape exception "denies married women protection against violent crime solely on the basis of gender and marital status." ${ }^{\prime 77}$ This was a violation of the Fourteenth Amendment's equal protection clause, and could not withstand even a rational basis review. West asked: "[w] hat possibly could be less rational than a statute that criminalizes sexual assault, and punishes it severely, unless the victim and assailant are married?'78

The end of West's talk made the most provocative, and relevant, claim. West argued that Congress, pursuant to its powers under Section 5 of the Fourteenth Amendment, should ban marital rape statutes to provide protection for women: "[w] hether or not the US Supreme Court or state supreme courts rule on the unconstitutionality of marital rape exemption, Congress has the power, the authority, and arguably the duty, to do so, under section five of the Fourteenth Amendment." She proposed a "Married Woman's Privacy Act" intended to "guarantee protection to all women against violent sexual assault." ${ }^{80}$ This proposed law would "prohibit irrational discrimination against married women in the making and enforcement of rape laws." 81

Later, Nourse attributed West's influence on the legislation as the most "dear[] and important." ${ }^{\prime 2}$ According to writer Fred Strebeigh, however, "[West] never envisioned her article would be picked up, within a few weeks of publication, by a Senate staffer with instructions to

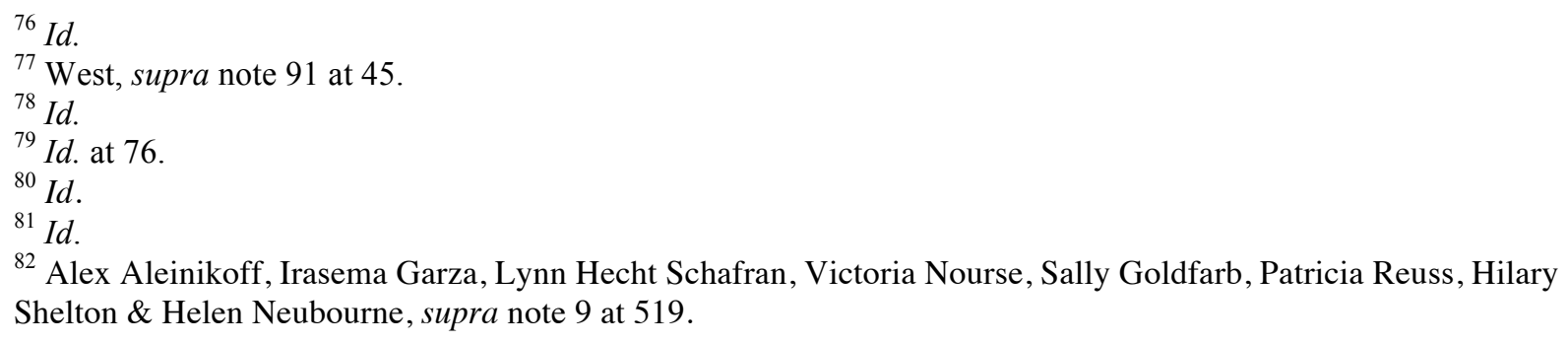


create new legislation for women." ${ }^{, 83}$ Indeed, West was preparing for an "imaginative talk at a low-profile law school" when she developed her bold remedy-i.e., the Married Woman's Privacy Act. ${ }^{84}$ But that is precisely what happened-Nourse adopted West's suggestion and ran with it. ${ }^{85}$

Nourse still needed the last piece of the puzzle to ensure that her legislation protected all women, not just the married ones, against all violence, and not just rape. To make this link, Nourse turned to the writings and political organizing of Catharine MacKinnon. ${ }^{86}$ In 1983 , MacKinnon and feminist theorist Andrea Dworkin authored a state statute that "recognize[d] pornography as a violation of the civil rights of women" and that provided victims with a civil remedy when, "they are coerced into pornography, when pornography is forced on them, when they are assaulted because of specific pornography," and most controversially, when they were “trafficked” in pornography. ${ }^{87}$ MacKinnon's statute was struck down on First Amendment grounds ${ }^{88}$ but its argument compelled West, and then Nourse. It used the model of the Civil Rights Act of 1871 to combat violence (specifically pornography) against women and argued that this violence was a form of discrimination. ${ }^{89}$ Nourse and Sally Goldfarb, a former law student of MacKinnon's and an attorney at National Organization for Women's Legal Defense Fund ("NOW LDF") working on the civil rights remedy, contacted MacKinnon for advice. ${ }^{90}$ She drew on her anti-pornography ordinance but encouraged expanding it to all violent acts against

\footnotetext{
${ }^{83}$ Strebeigh, supra note 8 at 335 (citing interview with West).

${ }^{84} I d$.

${ }^{85} I d$. at $331,335-36$.

${ }^{86}$ MacKinnon is a well-known feminist legal scholar and activist. Some of her many publications include: TOWARdS A FEMINIST THEORY OF THE STATE (1989); FEMINISM UNMODIFIED: DisCOURSE OF LIFE AND LAW (1987); Sex Equality. Sexual Harassment (2003); ARE WoMEN HuMAn?: AND OTHER INTERNATIONAL DialoGUES (2006).

${ }^{87}$ Strebeigh, supra n.4 at 336. For more information on the ordinance, see Catharine MacKinnon. FEMINISM UNMODIFIED: DiscourseS On LIFE AND LAW (1987); Catharine MacKinnon and Andrea Dworkin, IN HARM'S WAY: THE PORNOGRAPHY CIVIL RightS HEARINGS (1997).

${ }^{88}$ American Booksellers v. Hudnut, 771 F.2d 323 (7th Cir. 1985).

${ }^{89}$ Strebeigh, supra note 8 at 336.

${ }^{90} \mathrm{Id}$. at 344.
} 
women. Specifically, she advised that "[i]f Biden wants to do something for women, he should recognize rape and battering as federal sex-discrimination claims." ${ }^{91}$

Nourse combined these ideas to create the VAWA civil rights remedy.$^{92}$ Each source, however, was problematic for two reasons. First, although the Supreme Court upheld 42 U.S.C. $\S 1985$ (3) in Griffin, it was not a widely used statute. The Court read the statute's elements of conspiracy and intent narrowly, ${ }^{93}$ and has continued to do so. ${ }^{94}$ The statute is thus an "unwieldy means of protecting civil rights." 95 Additionally, although the VAWA civil rights remedy was based somewhat on $\S 1985$ (3), it was "unprecedented" and "departed, in significant ways from [existing] civil rights remedies." ${ }^{96}$ Unlike $§ 1985$ (3), the VAWA did not require conspiracy or an intent to cause a rights deprivation, but only that an act be "motivated by gender." Nourse was aware of how groundbreaking the civil rights remedy was: "[a]lthough existing civil rights remedies appear to be the templates [for the VAWA civil rights remedy], ... those remedies provide no analogue for the substantive right created by ... [the VAWA civil rights remedy], 'to be free' from gender-motivated violence." ${ }^{98}$ The VAWA civil rights remedy was thus based loosely on something that had not successfully fostered change, and was yet more controversial than its inspiration.

\footnotetext{
${ }^{91} I d$. (citing interview with MacKinnon).

${ }^{92}$ Id. at 313-44.

93 Griffin v. Breckenridge, 403 U.S. 8 (1971).

${ }^{94}$ United Brotherhood of Carpenters and Joiners of American v. Scott, 463 U.S. 825 (1983); Bray v. Alexandria Women's Health Clinic, 506 U.S. 263 (1993); Great American Federal Savings \& Loan Ass'n. v. Novotny, 442 U.S. 366 (1979).

95 John C. JefFries et. Al., Civil Rights Actions: Enforcing the Constitution 727 (2nd. ed. 2007).

${ }^{96}$ Nourse, supra n83 at 5.

${ }^{97}$ Victoria F. Nourse, Where Violence, Relationship, and Equality Meet, supra note 8 at 8-9.

${ }^{98} I d$. at 8 .
} 
Second, West and MacKinnon are unorthodox legal thinkers. MacKinnon was the founder of dominance or subordination feminist legal theory. ${ }^{99}$ This school offers a "sweeping critique of patriarchy"100 and argues that "inequalities women experience as sex discrimination in the economic, political, and familial arenas result from patterns of male domination."101 Subordination theory argues that "sexually predatory conduct," e.g., rape and sexual assault, "long constitutes a form of sexual discrimination." 102 The pornography ordinance that inspired the VAWA, and its contention that pornography constitutes discrimination, is the "most controversial" application of MacKinnon's work. ${ }^{103}$ Many feminists theorists have "resisted firmly" this position. ${ }^{104}$

West has also offered a comprehensive and biting critique of patriarchy. ${ }^{105}$ In the article that Nourse relied upon in crafting the civil rights remedy, West draws on subordination theory to “frame abused women's situations not simply as individual problems, but as a part of the overall institutional oppression of women." ${ }^{106}$ With her call for a Married Woman's Privacy Act, which directly inspired the VAWA, West went "as far as anyone in arguing that the state has a constitutional duty to eradicate private as well as public violence." ${ }^{107}$ These extreme views were even more radical given the political climate at the time. Many considered battering a "natural" occurrence and violence against women a "fringe" issue. ${ }^{108}$

\footnotetext{
99 See NANCy LeVIt AND Robert R.M. Verchick, FEMINIST LEGAL TheORY 22-26 (2006); Katherine T. Bartlett, "Perspectives in Feminist Jurisprudence," in FEMINIST JURISPRUDENCE, WOMEN, AND THE LAW: CRITICAL ESSAYS, ReseArCh AgENDA, AND BIBLIOGRAPHY, eds. Taylor et. al. 8-13 (1999).

${ }^{100}$ Levit and Verchick, supra note 117 at. 24.

${ }^{101} \mathrm{Id}$. at 22-23.

${ }^{102}$ Bartlett, supra note 117 at 9.

${ }^{103}$ Id. at 10 .

${ }^{104} \mathrm{Id}$.

${ }^{105}$ Robin West, Jurisprudence and Gender, 55 U. CHI. L. REV. 1 (1988).

${ }^{106}$ Bartlett, supra note 117 at 11-12.

${ }^{107} \mathrm{Id}$. at 12 n. 42 .

${ }^{108}$ Nourse, supra note 8 at 2. Nourse notes that: "Within this atmosphere, it might have seemed downright foolhardy to challenge the power of relationship to diminish violence by invoking the idea of gender equality. And yet, that is precisely what its sponsor, Senator Joseph Biden, did when he introduced the bill in June of 1990." Id. For a further
} 
Together, the work of MacKinnon and West, which Nourse used to build the civil rights remedy, was clearly outside the mainstream. This would prove to make the civil rights remedy difficult for attorneys to embrace, and for the judiciary and the press to fully conceptualize. The sources of inspiration had also not proven that they could inspire concrete change. This would significantly influence how, and how much, the statute would be used later in practice.

\section{Part III: At the Moment Of Its Passage, The Civil Rights Remedy Was "Relegated to A Symbolic Means of Fighting Discrimination"}

Not surprising given its origins, the VAWA civil rights remedy was "very controversial from the outset." ${ }^{109}$ It was not preordained that the bill would become law. Securing passage required a "massive effort nationally over the course of four and a half years." ${ }^{110}$ Biden and his supporters organized a series of legislative hearings during this period to rally support for the legislation. The congressional record focused on two things: what the problem was and how the VAWA civil rights remedy would fix it. The remedy was needed to counter discrimination and gender-bias in state courts that prevented women from equal access to justice. The VAWA civil rights remedy sought to solve this problem by achieving the two goals its advocates articulated: providing a better forum and method for redress for victims of gender-violence and sending a symbolic message that violence against women violated a civil right. Establishing that there was a problem that needed to be solved, and spreading the symbolic message that this was a civil

discussion of the conservative political atmosphere during this period, and its implications for litigation campaigns, see McCann and Dudas, "Retrenchment... and Resurgence?" in CAUSE LAWYERS AND SOCIAL MOVEMENTS, eds. A. Sarat and S.A. Scheingold, 38 (2006).

${ }^{109}$ Sally Goldfarb, The Civil Rights Remedy of the Violence Against Women Act, supra note 83 at 393.

${ }^{110} I d$. at 391. Goldfarb described the push to pass the VAWA a "truly a grassroots effort....[T] he NOW Legal Defense and Education Fund had founded the National Task Force on the Violence Against Women Act, which ultimately encompassed more than 1000 organizations and individuals throughout the country: labor groups, women's groups, civil rights, religious organizations, community groups and so on, all of them concerned about the problem of rape, domestic violence and other forms of violence against women. It certainly was not the first time that a national coalition had been formed to pass federal legislation. But I think the coalition's extraordinary success was because the issue touched a nerve among so many American women." Id. at 395. In the conclusion, this paper will argue that the grassroots effort was not as significant as that which went into the passage of the Civil Rights Act of 1964. See infra. 
rights issue, occupied a significant portion of the hearings. The first goal, providing a better forum and method of redress for gender-violence claims, and precisely how this would be achieved, was completely overshadowed. This proved to be problematic - heavily emphasizing the symbolic solution to the problem made the civil rights remedy a self-fulfilling prophecy: it ultimately did nothing more than send a message.

VAWA advocates first focused on the problem: insufficient institutions to combat the epidemic of violence against women. Advocates argued that existing legal remedies available to victims of gender-motivated violence were deeply flawed. On the federal side — two civil rights laws addressed violence against women, but they were severely limited. Title VII, which prevented discrimination on the basis of sex in employment, applied only in the workplace. ${ }^{111}$ Senator Biden identified this narrow application in a congressional hearing, and noted that a woman who was raped in the workplace could sue for damages under Title VII but that one raped in the parking lot outside her workplace could not. ${ }^{112}$ Similarly, Title IX, which requires equal opportunity for the sexes and outlaws discrimination based on gender, is confined to educational institutions receiving federal funding. ${ }^{113}$ As one advocate put it: "[a]ntidiscrimination laws that promise equality in the workplace, in schools, in the community, and in the family, are worth little if our physical safety and bodily integrity are still at risk." ${ }^{114}$

A great deal of emphasis was placed on state judicial systems' failure to address adequately violence against women. First, testimony reported on the formal barriers to equal treatment: "[c]orroboration and utmost resistance rules in rape cases ... spousal immunities from

\footnotetext{
${ }^{111} 42$ U.S.C. $\S 2000(\mathrm{e})$.

${ }^{112}$ Legislation to Reduce the Growing Problem of Violent Crime Against Women, Part I: Hearing Before the S. Committee on the Judiciary, 101st Congress (1990) (Statement of Joseph R. Biden, Chairman, S. Committee on Judiciary). Part I, Serial No. J-101-80. at 108.

${ }^{113} 20$ U.S.C. $\S \S 1681-88$.

${ }^{114}$ Sally Goldfarb, supra note 83 at 392.
} 
rape and battery charges ... special jury instructions casting doubts upon rape victims' credibility ... legal treatises openly recommending that all rape victims be examined by a psychiatrist." 115 Even more important was the de facto discrimination women faced. A 1991 Senate Report collected the findings of a series of task forces ${ }^{116}$ that evaluated state court proceedings and collectively found "overwhelming evidence that gender bias permeates the court system and women are most of its victims." ${ }^{117}$ Experts testified to these conclusions at legislative hearings. A lawyer who led a commission studying gender bias in Florida courts noted that despite the state rape shield law and other de jure protections for women, "rape remains a crime in which the victim is often as traumatized by the system as they are by the assailants themselves." ${ }^{118}$ Helen Neuborne, the Executive Director of the NOW LDF, reported that even state statutes intended to protect women consistently failed: "judicial enforcement ... is often influenced by common law heritage and cultural stereotypes that treat wives as the property of their husbands, sanction wife abuse, and assume that the victim provoked the violence." ${ }^{\prime 19}$ Survivors testified about their negative experiences with state judicial proceedings — one recalled seventeen years of spousal abuse, citing "black eyes, bruises, a broken ear drum, and ... being beaten while I was

\footnotetext{
${ }^{115}$ Victoria F. Nourse, supra note 8, at 9 (citing The Violence Against Women Act of 1991, 102d Congress (1991) Senate Report No. 197 at 43-48).

${ }^{116} \mathrm{~A}$ series of task forces in the 1980 s, organized primarily by the National Association of Women Judges (NAWJ) and the NOW Legal Defense Fund, discovered that state courts were permeated by gender bias. One of the first studies produced, compiled by a task force in New York, found: "[t]he Task Force has concluded that gender bias against women litigants, attorneys, and court employees is a pervasive problem with grave consequences. Women are often denied equal justice, equal treatment, and equal opportunity. Cultural stereotypes of women's role in marriage and in society daily distort courts' application of substantive law." Strebeigh, supra note 8, at 385 (citing Report of the New York Task Force on Women in the Courts, reprinted in 15 FORDHAM URB. L.J. 1, 15 (1986-87). For a further discussion of the deficiency of state court responses to violence against women, see Brief for Arizona and 34 other States as Amici Curiae Supporting Petitioner, United States v. Morrison, 521 U.S. 598 (2000) (Nos. 99 5, 99-29).

${ }^{117}$ The Violence Against Women Act of 1991, 102d Congress (1991) Senate Report No. 197 at 43-44.

${ }^{118}$ Violence Against Women: Victims of the System, Committee on the Judiciary of the United States Senate, 102d Congress, (1991) (Testimony of Gill Freeman, chair, Florida Supreme Court Gender Bias Study Implementation Commission, Miami, FL) Hr. 102-369, at 135.

${ }^{119}$ Women and Violence: Legislation to Reduce the Growing Problem of Violent Crime Against Women, 101st Congress (1990) (Testimony of Helen Neuborne, Director of NOW LDF Fund). No. 101-939, at 57.
} 
pregnant." ${ }^{120}$ When she, "turned to the justice system, for help, especially financial, [she] was cruelly disappointed." 121

The VAWA civil rights remedy's first goal was fixated on improving protection for women by moving these claims in to federal court, and out of biased and unfair state courts. Senator Biden stated that he "want[ed] women to be able to get into the best court system in the world, with the most educated judges in the world and with a set of rules and regulations and a degree of sensitivity that is uniform." ${ }^{122}$ However, there was little discussion in the legislative history concerning who would bring these claims under the VAWA in federal court, how an effective lawsuit would bring redress to victims, and how these claims together would reduce violence against women. Some precise parameters of the statute were debated - the definitions of the phrases "crime of violence" and "motivated by gender" were significantly discussed, ${ }^{123}$ and part of a hearing was devoted to the constitutionality of the statute. ${ }^{124}$ But there was almost zero discussion of how the VAWA would be used by plaintiffs and attorneys, and how this might inspire change. ${ }^{125}$

The American Civil Liberties Union ("ACLU”), was among the few of the participants in Congressional hearings to focus on the use of the civil rights remedy in practice, and they concluded that it "practical considerations render [the civil rights remedy] ineffective for broad-

\footnotetext{
${ }^{120}$ Women and Violence: Legislation to Reduce the Growing Problem of Violent Crime Against Women, $101 \mathrm{st}$ Congress (1990) (Testimony of Tracy Motuzick). No. 101-939, at 88.

${ }^{121}$ Id. at 90 .

${ }^{122}$ Legislation to Reduce the Growing Problem of Violent Crime Against Women, Part I: Hearing Before the S. Committee on the Judiciary, 101st Congress (1990) (Statement of Joseph R. Biden, Chairman, S. Committee on Judiciary). P. 2. For a comparison of the federal and state courts' competence, and an argument that federal courts are more sophisticated, see Brett Neuborne, The Myth of Parity, 90 HARV. L. REV. 1105 (1977). (

${ }^{123}$ For a useful summary of the debates over the precise language of the statute see Nurse, supra note 8 at 12-16, 2633. Ultimately, "motivated by gender" was defined as "an animus based on the person's gender" and "crime of violence" as behavior that constituted a felony. See 42 U.S.C. $\$ 13981$.

${ }^{124}$ Violence Against Women: Victims of the System, Committee on the Judiciary of the United States Senate, 102d Congress, (1991) (Statements, Testimony and Panel Discussion of Professors Burt Neubone and Cass Sunstein). Hr. 102-369, at 84-131.

${ }^{125}$ For a review of all the legislative history, see Nurse, supra note 8.
} 
based litigation purposes." ${ }^{126}$ As a result, the organization, typically a supporter of leftist

legislation, did not support the remedy. Their central argument was that a majority of defendants

sued under the civil rights remedy would not be able to pay judgments. ${ }^{127}$ Aside from their

statement, there was little dialogue about this concern. ${ }^{128}$

\begin{abstract}
${ }^{126} I d$.
${ }^{127}$ Id. To reach their conclusion the ACLU cited a report of the Judicial Conference of the United States which stated that seventy-five percent of criminal defendants in rape and assault cases are appointed public defenders, and therefore would not have significant resources to warrant a civil suit. They also cited a statistic that in the majority of reported cases of rape, the identity of the attacker is unknown, which would make a civil suit impossible. Id.

${ }^{128}$ If the ACLU's prediction was realized during the years the civil rights remedy existed is contested. One Note has argued that the primary reason the civil rights remedy was not actively used in practice was for this reason. See Regen, supra note 28 at 803-4 (arguing that because "violence against women predominates against poor women and women of average means" their abusers are generally "unlikely to have cash on hand" to pay judgments). This paper disputes this claim with three arguments. For one, violence against women "cuts across all racial, religious, ethnic, and socioeconomic lines." Crimes of Violence Motivated by Gender: Hearing before the H. Subcommittee of Civil and Constitutional Rights of the Committee on the Judiciary, 103rd Congress, Serial No. 51 (1993) (prepared statement of NOW Legal Defense Fund) and is not only a poor persons' problem. The American Psychological Association reports that "exposure to violence transcends socioeconomic status, affecting all levels of income, education, and occupation." American Psychological Association, "Violence and Socioeconomic Status FactSheet," available at https://www.apa.org/pi/ses/resources/publications/factsheet-violence.aspx. It has been reported that women of lower socioeconomic status are more likely to be the victims of domestic and sexual violence, $i d$., but this does not indicate that they are the only victims. Second, the VAWA was structurally designed to allow victims without significant financial means to bring claims. The statute provided for both attorneys' fees and punitive damages as added incentives for attorneys, and plaintiffs. See 42 U.S.C $\$ 13981$.Third, while it is true that some women of limited means may have not engaged in VAWA suits because of a lack of knowledge of or resources to support a claim, given that the rates of violence against women are so high, this cannot be the sole reason why the VAWA did not produce much litigation. For example, one study estimated that there were 346,000 rapes per year. Department of Justice, Bureau of Justice Statistics, "Criminal Victimization 2012," available at http://www.bjs.gov/content/pub/pdf/cv12.pdf. If ten percent of victims brought claims, this would be close to 35,000 claims per year.

This argument is bolstered by the views of opponents of the civil rights remedy, who believed that it would produce a great volume of litigation. Chief Justice Rehnquist, the most important opponent of the VAWA, spoke out against the civil rights remedy on several occasions prior to its passage. He worried that the remedy would overload the federal courts and result in a "caseload crisis." Strebeigh, supra note 8 at 353-63. Two reports also predicted such an increase. A Judicial Impact Statement estimated that the remedy would increase the federal courts' docket by four percent, or more than 14,000 cases per year, and cost the system 43.6 million dollars. Id. at 357. (The report reached this conclusion based on the following: the committee added the number of rapes in the US in which women knew their attackers $(15,000)$ to the estimated number victims of other assaults who were likely to bring suits to "punish" their attackers $(38,000)$. The report then speculated that one-fourth of these women would be likely to bring suits, based on the premise that three quarters of defendants in rape and assault trials employed public defenders and thus only one-fourth would be worth suing.). An ad-hoc committee from the Judicial Conference of the United States, also assembled by predicted that the VAWA would double the size of the federal docket. Id. at 359 (This figure was based on the estimate that there were three million domestic relations cases in the state courts per year, and ten percent of these would become VAWA claims, or 300,000 ).
\end{abstract}


The second purpose of the VAWA, "declar[ing] for the first time that crimes of violence motivated by the victim's gender are a violation of the victim's civil rights," ${ }^{\prime 29}$ was, in contrast, significantly highlighted. Activists stated that this goal "was the most important of all."130 According to NOW leader Sally Goldfarb, women and girls were "relegated to a form of second class citizenship" because of gender-motivated violence. ${ }^{131}$ The civil rights remedy was created, in large part, to spread awareness that rape and domestic violence are "a form of discrimination," and send a symbolic, empowering message that the federal government stood to protect against this type of harm. ${ }^{132}$

Senator Biden continually emphasized this point in Congress. He stated that "[n]inetyseven percent of all sex crimes in this country are sex crimes against women....A rape or a sexual assault should be deemed a civil rights crime just as hate beatings aimed at blacks or Asians are widely recognized as violations of their civil rights." ${ }^{133} \mathrm{He}$ continued: "[c]reating a civil rights remedy can never blunt the pain that the survivor of a sex crime feels, but it does say that we as a nation, as a whole nation, will not tolerate crimes perpetrated against women simply because they are women." ${ }^{134}$ At a hearing on implementation after the remedy was passed, Senator Biden declared that the VAWA served as protection for women whose "civil right to be left alone" had been violated. ${ }^{135}$

\footnotetext{
${ }^{129}$ Alex Aleineikoff, Irasema Garza, Lynn Hecht Schafran, Victoria Nourse, Sally Goldfarb, Patricia Reuss, Hilary Shelton, Helen Neubourne, supra note 9 at 519 (2010).

${ }^{130} I d$.

${ }^{131}$ Sally Goldfarb, supra note 83 at 392.

${ }^{132} I d$.

${ }^{133}$ Legislation to Reduce the Growing Problem of Violent Crime Against Women, Part I: Hearing Before the S. Committee on the Judiciary, 101st Congress (1990) (Statement of Joseph R. Biden, Chairman, S. Committee on Judiciary). P. 4-5 (not sure I need page number).

${ }^{134} I d$. at 5 .

${ }^{135}$ The Implementation of the Violence Against Women Act Provisions of the Violent Crime Control and Law Enforcement Act (Public Law 103-322): Hearing Before the S. Committee on the Judiciary, 103rd Congress (1994) (Statement of Joseph R. Biden, Chairman, S. Committee on Judiciary).
} 
Senator Biden bluntly acknowledged that he "was under no illusions that this legislation is going to stop violence against women." ${ }^{136} \mathrm{He}$ outright declared that his intention with the remedy was not to end all violence against women, but to begin the process of "changing the nation's attitude" about the problem. ${ }^{137} \mathrm{He}$ stated:

I don't expect that making this a civil rights violation will solve this problem. People will not say 'I was thinking of committing a crime of violence and raping a woman, but now that it is a civil rights violation, I won't do it because I may be sued in federal court.' But it does say-not unlike what President Kennedy said about the need to deal with the civil rights of Black Americansthere is a need for the national psyche to acknowledge that there is something horribly wrong. The law should reflect this attitude. ${ }^{[138]}$

Senator Biden's argument was not unsupportable. One could read his point to rest on the premise that the two parts of the VAWA would work in tandem to improve the situation. The federal funding in the VAWA — for things like rape crisis centers, victim hotlines, improved safety features in high-risk areas, training for police officers - would help lower rates of violence against women in a concrete way. At the same time, the passage of the civil right remedy would heighten awareness of the problem, and send a message to "force ... debate and consciousness" about the epidemic rates of violence against women in the United States. ${ }^{139}$

Senator Biden's constant framing of the statute in this way may have made cognitive sense, but it limited future use of the civil rights remedy. By repeatedly using language highlighting the symbolic message of the civil rights remedy, Senator Biden undermined its functional purpose: providing a better forum for redress for victims. The civil rights remedy sent a message, but the overemphasis on this message made it seem like sending it was the remedy's

\footnotetext{
${ }^{136}$ Legislation to Reduce the Growing Problem of Violent Crime Against Women, Part I: Hearing Before the S. Committee on the Judiciary, 101st Congress (1990) (Statement of Joseph R. Biden, Chairman, S. Committee on Judiciary) at 11.

${ }^{137} I d$. at 2

${ }^{138} I d$.

${ }^{139} I d$. at 111.
} 
sole purpose. The ACLU, in its opposition to the remedy stated its fear that the VAWA would be "relegated to only a symbolic means of fighting discrimination." ${ }^{140}$ The ACLU based this prediction on their belief that "practical considerations" would prevent the VAWA civil rights remedy from effective use. ${ }^{141}$ Even before these considerations impeded the civil rights remedy in practice, ${ }^{142}$ it was "relegated to a symbolic form of fighting discrimination" because advocates, in their quest to gain support and make it law, focused only on its symbolic form.

\section{Part IV: Only Individual Attorneys Brought Claims And A Central Organization Did Not Assist Them Or Lead A Litigation Campaign}

Despite its radical origins, and the fierce debate over its passage, the VAWA was passed in 1994. What happened next? The fifty-nine cases studied reveal two trends. First, the cases were brought all over the country; no one jurisdiction produced a large proportion of the opinions. The Southern District of New York had the most at five. ${ }^{143}$ Even more important were the lawyers who brought these claims. Like the cases, they were regionally disparate. They were individual practitioners, operating solo or in small firms, with limited resources. Few lawyers filed more than one claim. Crucially, these lawyers were not part of a coordinated litigation campaign attempting to bring a significant number of cases.

Some lawyers were exceptions to this trend and were involved in more than one case, but these lawyers still operated independently and without the resources of a central organizing institution. For example, the lawyer who initially filed Morrison, Eileen N. Wagner, operates as

\footnotetext{
${ }^{140}$ Crimes of Violence Motivated by Gender: Hearing before the H. Subcommittee of Civil and Constitutional Rights of the Committee on the Judiciary, 103rd Congress, Serial No. 51 (1993)(prepared statement of American Civil Liberties Union).

${ }^{141}$ Id.

${ }^{142}$ For a discussion of the limitations of the VAWA in judicial opinions, see infra part VI.

${ }^{143}$ See Crisonino v. New York City Housing Authority, 985 F. Supp 385 (S.D.N.Y 1997); Glendora v. Pinkerton Security and Detective Services, 25 F. Supp 447 (S.D.N.Y. 1998) Ericson v. Syracuse University, 45 F. Supp 2d 344 (S.D.N.Y 1999): Wilson v. Diocese of New York of Episcopal Church, 96 CIV. 2400 (JGK), 1998 WL 82921 (S.D.N.Y. Feb. 26, 1998) (unpublished); Jugmohan v. Zola, 98 CIV. 1509 (DAB), 2000 WL 222186 (S.D.N.Y. Feb. 25,2000 ) (unpublished).
} 
a "sole practitioner law firm located in the Northern Neck of Virginia." ${ }^{144}$ Wagner represented Christy Brzonkala in the Western District of Virginia when she initially sued her two attackers for 8.3 million dollars, the amount the Virginia Tech football team won that year in the Sugar Bowl. ${ }^{145}$ Wagner, a college English professor before attending law school, specializes in representing plaintiffs in employment suits against universities. ${ }^{146}$ In a newspaper interview before the district court argument on the constitutionality of the VAWA, Wagner said, "I'm just another woman out there trying to make sure the world is safe for other people ... that's what we [herself and Brzonkala] want, for education to be safe and open for everyone."'147 Wagner also revealed a personal connection: she herself was sexually assaulted in graduate school, an experience which motivated her to get involved in this work and that which helped her ensure clients, "you are not alone." ${ }^{148}$ Wagner continued to be involved with the Morrison case after it was appealed to the Fourth Circuit and the Supreme Court, but she did not argue at either levelthe United States and the NOW LDF intervened to handle this role. ${ }^{149}$ Wagner also brought a similar VAWA claim in a suit against Virginia State University for its treatment of a sexual assault victim gang raped in a campus dorm..$^{150}$

\footnotetext{
144 "Eileen N. Wagner, Attorney at Law," available at http://eileenwagner-attorney.net/.

${ }^{145}$ See Brzonkala v. Virginia Polytechnic and State University, 935 F. Supp. 779 (W.D.Va 1996).

146 "Eileen N. Wagner, Attorney at Law," available at http://eileenwagner-attorney.net/.

${ }^{147}$ Lawyer Taking on High-Profile Case: Late Start at Career Meant Wagner Needed to Blossom Quickly, THE FREE LANCE STAR, May 7, 1996.

${ }^{148} I d$.

${ }^{149}$ Wagner was listed on record as an attorney who briefed the case when it was appealed to the Fourth Circuit and the Supreme Court, but she did not argue it at either level. NOW LDF and the Justice Department intervened in the litigation at these stages. See Brzonkala v. Virginia Polytechnic Inst. \& State Univ., 132 F.3d 949 (4th Cir. 1997) on reh'g en banc, 169 F.3d 820 (4th Cir. 1999) aff'd sub nom. United States v. Morrison, 529 U.S. 598, 120 S. Ct. 1740, 146 L. Ed. 2d 658 (2000); United States v. Morrison, 529 U.S. 598.

${ }^{150}$ See Thorpe v. Virginia State Univ., 6 F. Supp. 2d 507 (E.D. Va. 1998). In both this case and Brzonkala, Wagner also sued under Title IX, and a settlement was reached for these claims. See "Eileen N. Wagner: Important Litigation," available at http://eileenwagner-attorney.net/gpage2.html.
} 
Two lawyers in Colorado also were invested in filing VAWA cases. Darold Kilmer and Mari Newman operate a civil rights based law firm in Denver, ${ }^{151}$ and after passage of the VAWA they sought to assist victims of sexual assault by bringing suits under the VAWA civil rights remedy. Kilmer and Newman represented plaintiffs in two such cases, both of which arose out of incidents of rape in the workplace. ${ }^{152}$ The attorneys represented a nurse who sued her former supervising doctor after he raped her at work. ${ }^{153}$ The claim under the VAWA survived a motion to dismiss, and the case settled for $\$ 25,000 \cdot{ }^{154}$ The two also represented an employee of a restaurant who sued her former supervisor, after he used physical strength to trap her after work and forcefully rape her. ${ }^{155}$ The supervisor was convicted of second-degree assault in state court for the same incident. ${ }^{156}$ The woman was granted summary judgment against the supervisor. ${ }^{157}$

Kilmer and Newman educated other attorneys about the VAWA civil rights remedy and encouraged them to bring claims. They published an article in "Colorado Lawyer" describing the remedy's history and explaining how to satisfy successfully its elements. ${ }^{158}$ They wrote that the "important new civil rights remedy has been overlooked even by most civil rights attorneys." 159 The lawyers predicted that the Supreme Court would uphold the VAWA's constitutionality, and

151 “Kilmer, Lane \& Newman LLP: Our Mission,” available at http://www.killmerlane.com/about/our-mission.

${ }^{152}$ Darold Kilmer and Mari Newman were counsel for plaintiff in Blair v. All Stars Sports Cabaret, 87 F. Supp. 2d 1133 (D. Col. 2000) and Truong v. Smith, 28 F. Supp. 2d 626 (D. Col. 1998).

${ }^{153}$ Truong v. Smith, 28 F. Supp. 2d 626 (D. Col. 1998). See also Complaint of Plaintiff Randa Truong, Truong v. Smith, 28 F. Supp. 2d 626 (D. Col. 1998), No. 98-CV-00332 (source is on file with author).

${ }^{154}$ Judgment, Truong v. Smith, 28 F. Supp. 2d 626 (D. Col. 1998), No. 98-CV-00032 ("Consent judgment of the parties judgment entered in favor of plaintiff against defendant in the amount of $\$ 25,500$ on plaintiff's second amended complaint").

${ }^{155}$ Blair v. All Stars Sports Cabaret, 87 F. Supp. 2d 1133 (D. Col. 2000)

${ }^{156} \mathrm{Id}$. at 1135.

${ }^{157}$ Id. at 1137.

${ }^{158}$ Darold Kilmer and Mari Newman, "VAWA: A Civil Rights Tool for Victims of Gender-Motivated Violence," THE Colorado Lawyer, September 1999, Vol. 28, No. 9.

${ }^{159}$ Id. at 1. 
hoped that the "important addition to the arsenal of civil rights remedies"160 would continue to be used because it was a "valuable tool in combating and remedying gender motivated wrongs."161 Norm Pattis, a personal injury and constitutional tort litigator in Connecticut, was involved in two VAWA disputes, both of which involved former spouses. ${ }^{162}$ Pattis had successfully sued many police officers under $\S 1983$ and was attracted by the punitive damages and attorneys' fees made available under the VAWA. ${ }^{163}$ Pattis said he and his colleagues were "prepared to do with VAWA what we had done with 1983."164 Pattis' first experience with the VAWA was through his representation of a man whose former wife sued him under the VAWA. The former wife claimed that for 20 years he "systematically and continuously inflicted a violent pattern of physical and mental abuse and cruelty upon her" including "throwing her to the floor, kicking her, throwing sharp and dangerous objects at her, threatening to kill her, and destroying property." 165 Pattis lost that case, ${ }^{166}$ but later switched sides and represented a plaintiff bringing a VAWA claim against her husband in Tennessee. ${ }^{167}$ The plaintiff argued that during the courtship and throughout their marriage the "defendant engaged in controlling, deceitful and abusive behavior" and that she was the victim of "conspiracy, fraud, physical and sexual abuse, and emotional suffering." 168 This case survived a constitutional challenge, and Pattis' client received a settlement. ${ }^{169}$

\footnotetext{
${ }^{160} I d$. at 12 .

${ }^{161} \mathrm{Id}$.

${ }^{162}$ Pattis served as counsel for the defendant in Doe v. Doe, 929 F.Supp 608 (D. Conn 1996) and counsel for plaintiff in Seaton v. Seaton, 971 F. Supp 1188 (E.D. Tenn 1997).

${ }^{163}$ Telephone Interview with Norman Pattis, Pattis Law Firm (March 24, 2013). See also "Norm Pattis: Leading American Trial Lawyer," available at http://www.normpattis.com/.

164 Telephone Interview with Norman Pattis, Pattis Law Firm (March 24, 2013).

${ }^{165}$ Doe, 929 F.Supp. at 610.

${ }^{166} \mathrm{Id}$.

${ }^{167}$ Seaton, 971 F. Supp 1188.

${ }^{168}$ Id. at 1189.

${ }^{169}$ Telephone Interview with Norman Pattis, Pattis Law Firm (March 24, 2013).
} 
All of these practitioners were the types of lawyers one might expect to file a VAWA claim. Each had experience in an area similar to the VAWA. Kilmer and Newman were partners in a small firm specializing in civil rights violations ${ }^{170}$ Pattis was a member of a small regional firm and specialized in constitutional tort work, ${ }^{171}$ and solo-practitioner Wagner built her practice on employment and civil rights claims against universities. ${ }^{172}$ Each also had an incentive to become involved with VAWA—Kilmer, Newman and Wagner were dedicated to fighting violence against women, and Pattis was motivated by the potential for lucrative suits. Most important is the fact that they were acting alone and not in concert with an organization providing training and support. With the exception of Kilmer and Newman's article, ${ }^{173}$ there is no evidence that these lawyers were involved in coordinating a larger litigation campaign or cooperating with other similarly situated practitioners. The resources of these attorneys were therefore limited to the cases they could individually file and argue.

These lawyers were operating independently at least in part because women's rights organizations did not start a litigation campaign. The NOW Legal Defense Fund, the organization whose efforts were crucial to the passage of the VAWA, was involved in litigation during this time. According to Julie Goldschied, who served as the Acting Legal Director of the NOW LDF, the organization focused on two goals during this period. ${ }^{174}$ One was providing education to practitioners, primarily family law, employment, and civil rights lawyers, about the new civil rights remedy and encouraging its use. ${ }^{175}$ Second, NOW LDF intervened in cases and served as co-counsel, or intervened in cases and filed amicus briefs, in situations where the

\footnotetext{
170 “Kilmer, Lane \& Newman LLP: Our Mission,” available at http://www.killmerlane.com/about/our-mission.

171 Telephone Interview with Norman Pattis, Pattis Law Firm (March 24, 2013).

172 "Eileen N. Wagner, Attorney at Law," available at http:/eileenwagner-attorney.net/.

${ }^{173}$ Darold Kilmer and Mari Newman, “VAWA: A Civil Rights Tool for Victims of Gender-Motivated Violence,” THE COLORADO LAWYER, September 1999, Vol. 28, No. 9.

${ }^{174}$ Telephone Interview with Julie Goldschied, Professor, CUNY School of Law and Former Acting Legal Director of NOW Legal Momentum (formerly NOW Legal Defense Fund) (April 2, 2013).

${ }^{175} \mathrm{Id}$.
} 
statute's constitutionality was challenged, ${ }^{176}$ a feat that they achieved. ${ }^{177}$ Evidence of efforts the NOW LDF took to educate practitioners has not been located, ${ }^{178}$ making it difficult to measure the success of these attempts. One can speculate that education and outreach that was done may have only reached a small subset of all attorneys; NOW LDF and its sister association NOW, have consistently been recognized as one of the most liberal of women's rights organizations. Despite urging from "feminist groups and sympathetic politicians [who] advised NOW to moderate its goals and tactics ... NOW remained stubbornly outside the mainstream."179

What is clear is that the NOW LDF did not make original litigation, or the initial filing of VAWA civil rights suits, a priority during this period. The organization did not file any suits independently that have been located. ${ }^{180}$ It is not known why the organization made the choiceresource constraints may have been to blame or it may have been a strategic decision. ${ }^{181}$ More important than these possible motivations is the choice itself - by forgoing original litigation in

\footnotetext{
${ }^{176}$ Id; Hon. Mary Schroeder, Julie Goldscheid, Judith Resnik, Fred Strebeigh, \& Martha Davis, Panel Two: The Vawa Civil Rights Provision: Shaping It, Saving It, Litigating It, Losing It, supra note 29 at 548-49 ("Now Legal Defense [Fund] was involved in some of those cases as co-counsel and in many as amicus. In others we provided technical assistance to local lawyers bringing the claims.").

${ }^{177}$ Of the fifty-nine cases studied, NOW LDF intervened in six. See Appendix II for a list of these cases,

${ }^{178}$ Efforts to obtain resources from NOW LDF have been largely unsuccessfully, and as a result, the author of this paper has not been able to locate internal NOW LDF documents that may have shed light on these activities. The "history" section of the NOW LDF's website only emphasizes the goal of serving as an amicus or intervenor in constitutional cases. "Legal Momentum's History", available at https://www.legalmomentum.org/history. The site notes the organization's involvement in securing the passage of the VAWA (1991, 1994), writing amicus briefs in cases in which the VAWA's constitutionality was challenged (1997), and briefing and arguing the Morrison case before the Fourth Circuit and the Supreme Court (2000). Id. The history does not list educational efforts during this period or any efforts to recruit other lawyers to bring VAWA claims. Id.

${ }^{179}$ MARYANN BARAKSO, GOVERNing NOW: GRASSROOTS ACTIVISM IN THE NATIONAL ORGANIZATION FOR WOMEN 120 (2004).

${ }^{180}$ Research has not located any cases in which NOW LDF is listed as the original attorney. Goldschied stated that NOW provided "technical assistance" to local lawyers bringing claims, but this does not indicate that NOW encouraged the filing of these suits, or filed any themselves. See note 191 supra. For a full list of these cases and their citations, see Appendix II.

${ }^{181}$ Efforts to obtain resources from NOW LDF have been largely unsuccessfully, so an examination of their internal decision-making and resource allocation is not possible. 2003 is the most recent year for which financial information about NOW LDF is publically available, and the NOW LDF reported a total income of 7.2 million dollars and total expenses of 6.4 million dollars. "Legal Momentum Annual Report 2003," available at https://www.legalmomentum.org/sites/default/files/uploads/Legal\%20Momentum\%20FY\%202013\%20Annual\%20 Report.pdf. This is a significant budget that equates to over 8 million dollars today.
} 
favor of intervening in constitutional cases - a central organization did not lead a litigation campaign under the VAWA civil rights remedy.

This was also true because of another important circumstance: NOW LDF was operating alone. They were the only large-scale liberal organization that was working on the civil rights remedy after its passage. ${ }^{182}$ One key liberal organizing force—-the American Civil Liberties Union (ACLU) — did not support the remedy to any extent. ${ }^{183}$ The portion of the ACLU dedicated to women's issues, The ACLU Women's Rights Project, did not involve itself in any VAWA litigation. This organization states on its website that it "has argued more women's rights cases before the United States Supreme Court than any other organization and has done more work to promote women's liberty and equality than many organizations devoted exclusively to that goal. ${ }^{" 184}$ In the 1990s, the organization focused instead on reproductive rights and equal access to employment and education opportunities. ${ }^{185}$

The stories of these four attorneys, and the limited and lacking involvement of women's rights groups, is significant for two reasons. First, these four attorneys were the only lawyers identified that filed more than one VAWA claim. ${ }^{186}$ This is remarkable, and indicates that a

\footnotetext{
${ }^{182}$ There is voluminous evidence about the broad-based coalition that was organized to pass the VAWA, see supra note 123 , however, there is no evidence that these organizations were involved with bringing claims after the passage of the legislation.

${ }^{183}$ The organization did not believe that the remedy would actually reduce violence against women. See Crimes of Violence Motivated by Gender: Hearing before the H. Subcommittee of Civil and Constitutional Rights of the Committee on the Judiciary, 103rd Congress, Serial No. 51 (1993) (prepared statement of American Civil Liberties Union). The ACLU may also have been uncomfortable with the larger bill in which the VAWA was passed, Violent Crime Control and Law Enforcement Act of 1994, which was typically considered to hurt the rights of criminal defendants. For a discussion of the compromises some feminists and liberals made with conservatives in the 1990s over issues of crime and violence, and the consequences of these compromises, see MARIE GOTTSCHALK, THE PRISON AND THE GALlOWS: THE POlITICS OF MASS INCARCERATION IN AMERICA (2006).

${ }^{184}$ The ACLU Women's Rights: Proud History, Continuing Struggle. March 12, 2002. Available at https://www.aclu.org/womens-rights/aclu-and-womens-rights-proud-history-continuing-struggle ${ }^{185} \mathrm{Id}$.

${ }^{186}$ Preliminary research on the other lawyers involved in the VAWA cases studied suggests that they can be divided into two groups: (1) Attorneys like Wagner, Pattis, Newman and Kilmer, who had experience in a similar area and were actively interested in, and sought, VAWA claims; and (2) Attorneys who opportunistically added a VAWA claim onto an existing suit with many claims (such as one filed under Title VII). Both of these types of attorneys
} 
significant cadre of lawyers was not mobilized to bring claims under the civil rights remedy after it was passed. This was the result of the lack of the involvement of a central organization, and the multitude of factors catalogued in this paper - the civil rights remedy was extreme, its passage was controversial, and the judiciary and the press did not embrace or bolster the claims that were brought. The small number of lawyers involved in multiple claims is thus in some senses a product of these weaknesses. But it is also another cause of the civil rights remedy's failurebecause so few lawyers were bringing claims - there was very little litigation, and the civil rights remedy's ability to achieve its two goals was further impeded.

At a conference marking the fifteenth anniversary of the VAWA, Judge Mary Schroeder, of the United States Court of Appeals for the Ninth Circuit, made a provocative suggestion. She suggested that if supporters of the VAWA "could have organized a small band of advocates ... who could have been out there systematically litigating cases involving the civil rights provision and related issues we might have gotten another vote in Morrison. ${ }^{187}$ This paper does not fully embrace this bold claim and attempt to suggest that more lawyers would have changed Morrison's ultimate result. However, more lawyers, and thus more cases, would have bolstered the civil rights remedy and furthered its goals when it existed.

\section{Part V: Opponents Immediately Challenged The Statute's Constitutionality}

Those few attorneys who did bring claims under the civil rights remedy faced formidable opponents whose arsenal was quickly bolstered by a new weapon — a surprise Supreme Court decision that threatened to undermine the VAWA. Less than a year after the VAWA was passed, on April 26, 1995, the Supreme Court handed down an unexpected ruling in United States v.

support the argument made: lawyers bringing VAWA claims were not a part of a centralized campaign to do so and were operating solely with their own resources. A working list of these lawyers is on file with the author.

${ }^{187}$ Hon. Mary Schroeder, Julie Goldscheid, Judith Resnik, Fred Strebeigh, Martha \& Davis, supra note 29 at 548. 
Lopez. ${ }^{188}$ The Court held that Congress had exceeded its authority under the commerce clause in passing a statute that criminalized possessing a firearm in a school zone. ${ }^{189}$ This was the first time that the Supreme Court had struck down a piece of legislation on commerce clause grounds in over six decades. ${ }^{190}$ The decision propelled opponents of the VAWA to attack the civil rights remedy on constitutional grounds.

The first constitutional challenges to the VAWA came in early 1996 . One such challenge was asserted in the Brzonkala case in the Western District of Virginia ${ }^{191}$ filed by Wagner on December 12, 1995. ${ }^{192}$ On February 2, 1996, the defendants filed a motion to dismiss relying on Lopez to argue that the civil rights remedy was unconstitutional. ${ }^{193}$ The District Judge ruled in the defendant's favor. ${ }^{194}$ This ruling was appealed and overruled by a three-judge panel on the Fourth Circuit ${ }^{195}$, but then affirmed en banc. ${ }^{196}$ Given the high-profile nature of the incident, and the decision to strike the legislation, the case received a great deal of publicity. ${ }^{197}$

The constitutionality of the VAWA civil rights remedy was concurrently challenged in Connecticut. ${ }^{198}$ After a complaint was filed on December 22, $1995^{199}$, a motion to dismiss on

\footnotetext{
${ }^{188} 514$ U.S. 549 (1995).

${ }^{189} \mathrm{Id}$.

${ }^{190}$ The Supreme Court had last regulated Congressional power under the commerce clause during the New Deal. There is a debate among scholars if the court's changed direction in 1937 was an abrupt political move, or the result of a more gradual jurisprudential shift. For the latter argument, see Barry Cushman, Rethinking the New Deal Court, 80 VA. L. REV. 201 (1994). For a discussion of the response to and implications of the court's decision in Lopez, see Deborah Jones Merritt, Commerce!, 94 Mich. L. REV. 674 (1995).

${ }_{191}$ Brzonkala v. Virginia Polytechnic and State University, 935 F. Supp. 779 (W.D.Va 1996).

${ }^{192}$ Complaint of Plaintiff Christy Brzonkala, Brzonkala v. Virginia Polytechnic and State University, 935 F. Supp. 779 (W.D.Va 1996), No. 95-CV-01358.

${ }^{193}$ Brzonkala, 935 F.Supp. at 785-94; See also Motion to Dismiss by Defendants, Brzonkala v. Virginia Polytechnic and State University, 935 F. Supp. 779 (W.D.Va 1996), No. 95-CV-01358.

194 Brzonkala, 935 F.Supp. at 801.

195 Brzonkala v. Virginia Polytechnic Inst. \& State Univ., 132 F.3d 949 (4th Cir. 1997) on reh'g en banc, 169 F.3d 820 (4th Cir. 1999) aff'd sub nom. United States v. Morrison, 529 U.S. 598, 120 S. Ct. 1740, 146 L. Ed. 2d 658 (2000).

${ }^{196}$ Brzonkala v. Virginia Polytechnic Inst. \& State Univ., 169 F.3d 820 (4th Cir. 1999) aff'd sub nom. United States v. Morrison, 529 U.S. 598, 120 S. Ct. 1740, 146 L. Ed. 2d 658 (2000).

${ }^{197}$ See discussion of the press coverage of Morrison see infra part VII.

${ }^{198}$ Doe v. Doe, 929 F.Supp 608 (D. Conn. 1996).

${ }^{199}$ Complaint of Plaintiff Jane Doe, Doe v. Doe, 929 F.Supp 608 (D. Conn. 1996), No. 95-CV-02722.
} 
constitutional grounds was filed by the defendants on February 2, 1996 ${ }^{200}$ Unlike the Virginia case, the Judge denied the motion and found VAWA constitutional on June 19, 1996. ${ }^{201}$

These two constitutional challenges came from different sources. The defendants in Virginia were represented by the Center for Individual Rights (CIR), a conservative public interest law firm that opened in 1989. The founders, Michael McDonald and Michael Greve, started CIR in an "attempt to duplicate the success of liberal public interest law firms in the conservative public interest realm." ${ }^{202}$ They consciously organized as a "smaller, more specialized" firm that would be "better-able to utilize available outside resources," than previous conservative firms that had been too large internally to stay afloat. ${ }^{203}$ They aimed to focus on original litigation, rather than just writing amicus briefs, which were "cost-saving" but "largely ineffectual. ${ }^{204}$

In his study of the CIR, political scientist Steven M. Teles found that the organization did not typically go looking for plaintiffs. Instead, the CIR "adopted a market model of issue selection." ${ }^{205}$ Like the early NAACP, "CIR's cases selection was characterized by strategic opportunism: pursuing a range of theoretically attractive opinions and then throwing itself behind those that demonstrated traction in the courts and within their organizational network. ${ }^{{ }^{206}} \mathrm{CIR}$ 's early successes then attracted media attention, lead to the development of a network, and caused "a stream of potential litigants to present themselves to the organization." ${ }^{207}$ CIR's lawyers would then sort through the cases to find those most likely to be successful. This strategy promoted

\footnotetext{
${ }^{200}$ Motion to Dismiss of Defendant John Doe, Doe v. Doe, 929 F.Supp 608 (D. Conn. 1996), No. 95-CV-02722

${ }^{201}$ Doe, 929 F. Supp at 617.

202 "A Brief History of the CIR," available at http://www.cir-usa.org/history.html

${ }^{203} I d$.

${ }^{204} I d$.

${ }^{205}$ STEVEN M. TELES, THE RISE OF THE CONSERVATIVE LEGAL MOVEMENT: THE BATTLE FOR THE CONTROL OF THE LAW 229 (2008).

${ }^{206} \mathrm{Id}$.

${ }^{207} I d$.
} 
CIR's “core commitments: a method of organizing public interest law activism, a broad critique of the administrative state, and a set of roughly libertarian principles." ${ }^{208}$

CIR became involved with the Morrison case in precisely this fashion. According to an interview with McDonald:

All-let me repeat-all of the CIR cases that made it to the Supreme Court had an element of pure fortuitousness to them ...We got into the VAWA [Violence Against Women Act] Morrison case because John Jeffries - the UVA law prof who argued [on the opposing side in] Rosenberger - thought we were decent guys and when some local practitioner in Virginia called him for help in Morrison, because he didn't know about VAWA he said call CIR. Again, we didn't create Morrison. ${ }^{209}$

Despite not creating Morrison, once CIR became involved with the litigation, their role was significant. For one, they brought skilled litigators and sizeable resources to the case. ${ }^{210}$ Second, the CIR had cultivated a reputation for conservative advocacy success, including several Supreme Court victories. ${ }^{211}$ This, and the fact that district judge in the case was the first to rule the statute unconstitutional, attracted significant media to the case, and made the constitutional challenge to the VAWA quickly known around the country.

The defense lawyer who argued that VAWA was unconstitutional in Connecticut was not a member of a conservative public interest firm, but Norm Pattis, the personal injury and tort litigator described above. ${ }^{212}$ In an interview, Pattis described how he became involved with the case. ${ }^{213}$ A colleague of Pattis' handled a divorce case that had resulted in a significant amount of

\footnotetext{
${ }^{208} \mathrm{Id}$.

${ }^{209}$ Id.

${ }^{210}$ The founders of the CIR had been "important players in the evolution of the conservative legal movement." Id. at 222. "The emergence of a new generation of wealthy libertarians in the technology and finance sector also helped CIR reconcile its funding needs with its strategic ambitions." Id. at 227.

${ }^{211}$ CIR had several important victories at the Supreme Court before Morrison including challenges to the constitutionality of affirmative action in Gratz v. Bollinger and Grutter v. Bollinger and challenges to restrictions on free speech in Rosenberger v. Rector and Visitors of University of Virginia. Id. at 220.

${ }^{212}$ See supra Part IV.

213 Telephone Interview with Norman Pattis, Pattis Law Firm (March 24, 2013).
} 
litigation. ${ }^{214}$ When the wife then brought a claim under the VAWA, the case was assigned to Pattis. ${ }^{215}$ Pattis remembered making the novel constitutional argument, based on Lopez, in what he called a "deplorable motion to dismiss," an effort he did not expect to succeed. ${ }^{216} \mathrm{In}$ Connecticut, Pattis did lose, and the statute was upheld. ${ }^{217}$ The following year, Pattis would represent a VAWA claimant in Tennessee, and there he would argue that the statute was constitutional. ${ }^{218}$

It appears that most lawyers bringing constitutional challenges were like Pattis, ordinary practitioners - often specializing in family law, civil rights litigation, or employment discrimination — who used the constitutional argument as a creative way to advocate for their clients. ${ }^{219}$ Many of them likely based their arguments on the CIR's, following their successful challenge in Virginia. The CIR is the only conservative public interest group that has been located which served defendants in VAWA civil rights cases.

Whatever their source, these constitutional challenges had an important impact on the VAWA's chance for success. The constitutionality of the statute was challenged in thirteen subsequent cases, following the two described above. ${ }^{220}$ Much of judicial adjudication of VAWA cases was devoted to this issue, rather than the merits of a claim. While the majority of courts upheld the statute's constitutionality, three did not. ${ }^{221}$ It soon became clear that the Supreme Court would ultimately decide the issue. This created a great deal of uncertainty. Many

\footnotetext{
${ }^{214} \mathrm{Id}$.

${ }^{215} I d$

${ }^{216} \mathrm{Id}$.

${ }^{217}$ Doe v. Doe, 929 F.Supp 608 (D. Conn 1996).

${ }^{218}$ Seaton v. Seaton, 971 F. Supp 1188 (E.D. Tenn 1997).

219 This conclusion is based on the author's initial survey of all the lawyers involved in cases under the civil rights remedy. A working list is on file with the author.

${ }^{220}$ Only two courts agreed with the Western District of Virginia and found the statute unconstitutional. See Bergeron v. Bergeron, 48 F.Supp. 2d 628 (M.D. La. 1999); Santiago v. Alonso, 96 F.Supp 2d 58 (D. P.R. 2000).

${ }^{221}$ See the discussion of the judicial response to the VAWA civil rights remedy, infra Part VI.
} 
attorneys, plaintiffs, and activists may have decided to wait until the constitutionality was ruled on before bringing their claims. After Morrison, the chance was foreclosed.

Also, as will be described below, ${ }^{222}$ the majority of the press focused on the Morrison litigation, and the constitutional issues surrounding the VAWA. This meant that many potential practitioners only heard about the law's challenges, rather than its successes. This prevented word about the VAWA from spreading to lawyers, plaintiffs, and activists through media channels, and furthered stifled litigation under the civil rights statute.

\section{Part VI: The Judiciary Did Not Embrace the Civil Rights Remedy}

The cases that were brought under the civil rights remedy faced yet another hurdle in court apart from the constitutional challenges themselves: a skeptical and divided judiciary. During debates over passage of the bill Chief Justice Rehnquist actively spoke out against the civil rights remedy. ${ }^{223}$ The Conference of Chief Justices adopted a resolution opposing the VAWA, and a committee of the Judicial Conference published a report arguing against it. ${ }^{224}$ Despite this resistance, the bill passed. However, some judges' lack of support for the civil rights remedy continued after it became law. As a result, the judiciary did not wholeheartedly embrace the civil rights remedy before Morrison. ${ }^{225}$ This, in turn, deterred litigation under the statute and

\footnotetext{
${ }^{222}$ See the discussion of the press' coverage of the civil rights remedy, infra part VII.

${ }^{223}$ The first time Rehnquist spoke out against the bill was during his annual "Year-End Report on the Federal Judiciary" in December 1991. There, he stated: "the bill's broad definition of criminal conduct is so open-ended," and its "new private right of action so sweeping," it "could involve the federal courts in a whole host of domestic relations disputes." Congressional addition of VAWA to what he called the federal "caseload crisis" could result in "degradation in the high quality the nation has long expected of the federal courts." In a speech to the American Bar Association on February 4, 1992, Rehnquist again argued that the proposed civil rights protections for women would unnecessarily expand the jurisdiction of federal courts. Strebeigh, supra note 8, at 353-63.

${ }^{224} I d$.

${ }^{225}$ This position is in direct tension with another commentator, who collected the rhetoric of many of the cases in which the court's constitutionality was upheld and concluded that, "the vast majority of courts to consider the Act accepted Congress's characterization of the statute as a civil rights remedy." Sarah F. Russell, Covering Women and Violence: Media Treatment of Vawa's Civil Rights Remedy, 9 Mich. J. Gender \& L. 327, 392 (2003). This is true of the twelve opinions that found VAWA constitutional, but it is only part of the story. This paper argues that when the
} 
hindered the VAWA's symbolic goal—recognition that violence against women was a civil rights issue.

The great majority of opinions that ruled on the constitutionality of the civil rights remedy before Morrison upheld the statute, ${ }^{226}$ but the majority of claims that adjudicated a VAWA merits claim found for the defendants. ${ }^{227}$ Opinions that upheld the VAWA, found for the plaintiffs, or expanded liability under the statute, looked similar to one another. Opinions that, on the other hand, invalidated the statute or found for defendants, looked very different from the favorable opinions, both in form and substance. A canvassing of both types of opinions will show that the judiciary was not united in support for the civil rights remedy when it existed. Their vacillation was yet another obstacle the civil rights remedy faced prior to Morrison.

Opinions that found the VAWA constitutional or found in favor of the plaintiffs referred to the VAWA as a "civil rights" statute or remedy, rather than as a "civil remedy" or "civil cause of action." ${ }^{\prime 22}$ Many of these opinions began with a description of the gruesome violence that gave rise to the VAWA claim. In one case, the court noted that the defendant assaulted the plaintiff while she was "severely ill” by "forcefully remov[ing] plaintiff”s pantyhose against her will and penetrat[ing] plaintiff's vagina with his penis." ${ }^{929}$ In another case, the court cited the plaintiff's complaint alleging that the defendant's actions included "throwing her [the plaintiff] to the floor,

other forty-seven opinions that considered a VAWA claim are considered, the judiciary's analysis and rhetoric presents a more muddled picture.

${ }^{226}$ Twelve opinions upheld the constitutionality of the statute. Three struck it down. A list of these cases is available in Appendix II.

${ }^{227}$ The author's current count indicates that of the cases that did not rule on the constitutionality, twenty-seven found for defendants and nine for plaintiffs. The remaining seven opinions mention that a VAWA claim was brought but do not adjudicate it. The author is in the process of also evaluating the success of the VAWA claims where the constitutionality was upheld. A list of this breakdown is available in Appendix II.

${ }^{228}$ See Kuhn v. Kuhn, 98 C 2395, 1998 WL 673629 (N.D. Ill. Sept. 16, 1998) at *5 (calling the VAWA a "civil rights provision" and "civil rights remedy"); Peddle v. Sawyer, 64 F. Supp. 2d 12, 17 (D. Conn. 1999) (using the phrase a "right to be free from crimes motivated by gender"); Avila-Franco v. Worrell, 1998 U.S. Dist. LEXIS 12129 (D.D.C. 1998) at*3 ("Obviously, a woman's basic human right to be free from rape, including in the workplace, was not created by the VAWA. The Court therefore will not entertain variations on Defendants' argument that "there [are] no constitutional rights at issue here...only a statutory one.").

${ }^{229}$ Mattison v. Click Corp. of Am., Inc., CIV.A. 97-CV-2736, 1998 WL 32597, *2 (E.D. Pa. Jan. 27, 1998) 
kicking her, throwing sharp and dangerous objects at her, threatening to kill her ... forc[ing] her 'to be a 'slave' and perform all manual labor, including maintaining and laying out his clothes for his numerous dates with his many girlfriends and mistresses. ${ }^{{ }^{230}}$ In another case, the court described the series of events leading up to the claim as a "grim tale of domestic abuse" which ended in murder. ${ }^{231}$

Particularly in cases holding the VAWA constitutional, the court emphasized the unique purpose of civil rights laws. In the first case to do so, the court noted:

A plaintiff who obtains relief in a civil rights lawsuit does so not for himself [or herself] alone but also as a 'private attorney general,' vindicating a policy that Congress considered of the highest importance. The distinct societal function Congress sought to confer by enacting the VAWA civil remedy was to provide by a plaintiff's verdict a special societal judgment that crimes motivated by gender bias are unacceptable because they violate the victims' civil rights. ${ }^{232}$

Later courts that agreed with this ruling borrowed the same rhetoric. One proclaimed that, "the goal of deterring gender-motivated violence and providing redress for victims of such violence is certainly a worthy cause that is consistent with the constitutionally permissible ends of safeguarding civil rights. ${ }^{233}$

These supportive courts often drew parallels between the VAWA and other civil rights laws. The Southern District of New York held that the VAWA, "fits squarely within the tradition of federal civil rights legislation." ${ }^{.234}$ Another case analogized gender violence to "racial discrimination that re-necessitated congressional intervention in Heart of Atlanta Motel and Katzenbach." ${ }^{235}$ Yet another court noted that the "method of enforcing civil rights statutes, granting private litigants the statutory power to protect their own civil rights through the courts,

\footnotetext{
${ }^{230} \mathrm{Id}$.

${ }^{231}$ Culberson, 65 F. Supp. at 703.

${ }^{232}$ Doe v. Doe, 929 F.Supp 608, 616 (D. Conn. 1996) (internal citations and quotation marks omitted).

${ }^{233}$ Burgess v. Cahall, 88 F.Supp. 2d 319, 325 (D. Del. 2000).

${ }^{234}$ Crisonino v. New York City Housing Authority, 985 F. Supp 385, 397 (S.D.N.Y 1997).

${ }^{235}$ Culberson v. Doan, 65 F.Supp 2d 701, 713 (S.D. Ohio 1999).
} 
has been adopted by Congress in other statutory schemes and has continually received the approval of the federal courts. ${ }^{236}$

Comparisons to other civil rights law came in handy when courts expanded liability under the VAWA in order to rule for plaintiffs. For example, in Peddle v. Sawyer, an inmate sued prison officials after a guard sexually abused her. ${ }^{237}$ The legal question in the case was: could the inmate sue prison officials who were aware of the guard's prior sexual misconduct, but did not prevent or stop the conduct once it occurred? ${ }^{238}$ The court held that because the civil rights remedy was "in the tradition of Section 1981, 1983, [and] 1985(3)," it "affords victims of gender violence the same right of private redress in federal courts already afforded to victims of employment discrimination and civil rights violations. ${ }^{" 239}$ Therefore, supervisory liability was appropriate. The court then held that the inmate had sufficiently plead facts, that if true, established that the defendants "created a policy or custom of tolerating violations of inmates' rights" and denied the motion to dismiss. ${ }^{240}$ Other cases where plaintiffs had success follow a similar pattern. ${ }^{241}$

By describing graphic and disturbing incidents of gender-violence, and then comparing the VAWA to other civil rights laws, these courts were declaring that these acts were civil rights violations. That the courts were doing so in publically available judicial opinions symbolized the federal government's support for this new right. These opinions were doing the work envisioned by Senator Biden and the other activists when they emphasized in Congressional hearings the

\footnotetext{
${ }^{236}$ Liiu v. Striuli, 36 F. Supp. 2d 452, 478 (D. R.I. 1999).

${ }^{237}$ Peddle v. Sawyer, 64 F. Supp. 2d 12 (D. Conn. 1999). For over a year the guard "regularly grope[d] [her] in the breast and groin areas, and threaten[ed] her in order to compel her to engage in oral and vaginal sex." The guard arranged his schedule and "controlled" the inmate's "contact with other people and conduct" to allow frequent opportunities for assault. Id. at 14.

${ }^{238} I d$. at. $17-18$.

${ }^{239} \mathrm{Id}$. at 18

${ }^{240} I d$. at $18-19$.

${ }^{241}$ See Kuhn v. Kuhn, 98 C 2395, 1998 WL 673629 (N.D. Ill. Sept. 16, 1998); Avila-

Franco v. Worrell, 1998 U.S. Dist. LEXIS 12129 (D.D.C. 1998); Doe v. Walker, 193 F.3d 42 (1st Cir. 1999).
} 
symbolic message the civil rights remedy would send. ${ }^{242}$ Simultaneously, they were achieving the other goal of the VAWA by providing redress to victims who won their claims.

This, however, was not the only message that the judiciary sent. Other judges voiced an entirely different position in their rulings. Their opinions at least neutralized, and potentially diminished, the force of the judges who were furthering the VAWA's purpose. Together the judiciary sent a largely mixed message.

Three district courts found the VAWA unconstitutional, ${ }^{243}$ and a large majority of the other filed claims did not succeed on the merits. ${ }^{244}$ These courts did not describe the VAWA as a civil rights statute. The Western District of Virginia, the first court to strike down the VAWA, stated that the statute was "criminal in nature," ${ }^{245}$ and that it "creates a civil cause of action that seeks to vindicate a criminal act." ${ }^{246}$ The District of Puerto Rico indicated its discomfort with the legislation by using quotation marks around the term 'civil rights' and suggested that the statute should only "arguably" be considered like other federal civil rights laws. ${ }^{247}$ The Middle District of Louisiana, in denying that the legislation had a rational basis under the commerce clause, reasoned that, "this law is legislation regulating domestic violence." ${ }^{248}$ Courts that found against

\footnotetext{
${ }^{242}$ See supra Part III.

${ }^{243}$ Brzonkala v. Virginia Polytechnic \& State Univ., 935 F. Supp. 779, 781 (W.D. Va. 1996) rev'd sub nom. Brzonkala v. Virginia Polytechnic Inst. \& State Univ., 132 F.3d 949 (4th Cir. 1997) on reh'g en banc, 169 F.3d 820 (4th Cir. 1999) aff'd sub nom. United States v. Morrison, 529 U.S. 598, 120 S. Ct. 1740, 146 L. Ed. 2d 658 (2000); Bergeron v. Bergeron, 48 F.Supp. 2d 628 (M.D. La. 1999); Santiago v. Alonso, 96 F.Supp 2d 58 (D. P.R. 2000).

${ }^{244}$ See supra note 227 . One could argue that the fact that more plaintiffs lost than they won is itself significant. However, given that a majority of courts upheld that statute's constitutionality, and that some of the cases simply had bad facts, this claim is tenuous. Rather than focusing on the quantity of wins and losses, this paper will primarily analyze the rhetoric and analytical structure of the opinions to determine the judiciary's conceptual support for the remedy.

${ }^{245}$ Brzonkala, 935 F. Supp. at 790.

${ }^{246} \mathrm{Id}$. at 796.

${ }^{247}$ Santiago, 96 F.Supp $2 \mathrm{~d}$ at 67.

${ }^{248} \mathrm{Id}$. at 60 .
} 
VAWA defendants used similar terminology that masked the VAWA's function as a civil rights statute. $^{249}$

These courts did not typically provide a full account of the facts giving rise to the claim. ${ }^{250}$ The opinions' legal reasoning was also not fully developed. For example, a prisoner brought a claim against a parole officer who transported her to state prison and allegedly "made sexually explicit comments to her, fondled her, and rubbed her thighs and breasts. ${ }^{" 251}$ In its analysis, the court first referred to the civil rights remedy as "a civil cause of action." 252 Then the court made a brief ruling — under the "crime of violence" requirement of the VAWA, a felony was required and here the plaintiff had not alleged a specific felony. ${ }^{253}$ Without further description of the conduct or the potential felonies that it may have constituted, the court granted summary judgment to the defendant. ${ }^{254}$

Similarly thin reasoning was present in other cases. In one, an employee's suit for a "sexual assault" in the workplace was dismissed when the court determined that the allegation of "sexual assault" did not fulfill both the "crime of violence" and "gender-motivated" prongs of the VAWA with little discussion as to why this conclusion followed. ${ }^{255}$ In another, a petitioner sued the police department of a city for failing to investigate and warn citizens about a serial rapist that attacked her. ${ }^{256}$ In briefly dismissing the VAWA claim, the court stated that the plaintiff did not allege that the defendants committed a "crime of violence." ${ }^{257}$ The court did not

${ }^{249}$ See e.g., Wesley v. Don Stein Buick, 42 F. Supp. 2d 1192 (D. Kas. 1999); Sherman v. Helms, 80 F. Supp. 2 d 1365 (M.D. Ga. 2000).

${ }^{250}$ Bergeron 48 F. Supp. 2d at 638; Santiago, 96 F.Supp 2d at 60.

${ }^{251}$ Harris v. Zappan, CIV A 97-4957, 1999 WL 360203 (E.D. Pa. May 28, 1999).

${ }^{252} I d$. at $* 1$.

${ }^{253}$ Id. at $* 7$.

${ }^{254} \mathrm{Id}$.

${ }^{255}$ Braden v. Piggly Wiggly, 4 F. Supp.2d 1357 (M.D. Ala. 1998)

${ }^{256}$ Bridges v. City of Dallas, 1998 U.S. Dist. LEXIS 8925 [insert page] (N.D. Tex. 1998).

${ }^{257} \mathrm{Id}$. 
explore the possibility that the rapists' conduct would constitute that violence. The entire discussion of the VAWA claim was done in two sentences. ${ }^{258}$

It is noteworthy that the decision that delivered the final ruling on the civil rights remedy followed these trends. United States $v$. Morrison ${ }^{259}$ sent a clear message that protection from gender-motivated violence was not a civil right. The majority opinion did so in an indirect way: by holding that Congress exceeded its authority under the commerce clause in passing the VAWA. ${ }^{260}$ The court also rejected the argument that the VAWA was a valid exercise of Congressional power under the Fourteenth Amendment, by holding that it "is not directed at any state or state actor, but at individuals who have committed criminal acts motivated by gender bias." 261

Like the decisions that struck down or limited the VAWA, the majority opinion referred to the VAWA civil rights remedy as a "civil remedy" - the phrase "civil rights remedy" was not used. The words "civil rights" are only used in the majority opinion once. ${ }^{262}$ The majority opinion did not provide a detailed account of the facts giving rise to the claim, and simply stated that "Brzonkala alleges that, within thirty minutes of meeting Morrison and Crawford, they assaulted and repeatedly raped her." ${ }^{263}$ Ellipses were employed to edit out statements made by the defendants, and the court noted that the omitted portions were "vulgar remarks that cannot fail to shock and offend." ${ }^{264}$ In reaching this holding, the majority likened the civil rights remedy to

\footnotetext{
${ }^{258} \mathrm{Id}$.

${ }^{259} 529$ U.S. $598(2000)$

${ }^{260} \mathrm{Id}$.

${ }^{261} I d$. at 626

${ }^{262}$ Id. at 607. ("Congress explicitly identified the sources of federal authority on which it relied in enacting $\S 13981$. It said that a "Federal civil rights cause of action" is established "[p] ursuant to the affirmative power of Congress ... under section 5 of the Fourteenth Amendment to the Constitution, as well under section 8 of Article I of the Constitution.") The phrase was also used to represent the word "civil rights" in the Civil Rights cases.

${ }^{263} I d$. at 602 .

${ }^{264} I d$.
} 
other areas of the law, including criminal ${ }^{265}$ and family law, ${ }^{266}$ rather than other civil rights statutes. Just as the majority mimicked the opinions that had limited the civil rights remedy, the dissent borrowed from those decisions that further the goals of the civil rights remedy. The dissenters in Morrison used the term "civil rights remedy" to describe the statute. ${ }^{267}$ The dissent in the Fourth Circuit decision, which found the statute to be constitutional, provided an extremely detailed overview of the facts. ${ }^{268}$

Morrison itself then is a mirror of the lower courts' jurisprudence on the civil rights remedy before it reached the Supreme Court. The collection of opinions is a deeply conflicted one. Some claims embraced the civil rights remedy and used it as a tool to provide redress to victims of gender-violence and send a message about the issue, precisely as advocates imagined. At the same time, a high percentage of the claims failed on the merits and did not contain civil rights rhetoric or analysis. This suggests that some courts did not recognize the VAWA as civil rights legislation and were hostile to civil rights remedy plaintiffs. Together, this collection of opinions blur the image of a judiciary that was supposedly united in its support for the VAWA, save a few outliers, prior to the Supreme Court's decision in Morrison. ${ }^{269}$ Because of these opposing positions, the goals of solidly affirming that gender-violence was a civil rights violation, and bringing redress to a substantial number of plaintiffs, were not significantly furthered by the nation's courts in the five years before Morrison's holding.

\footnotetext{
265 "Indeed, if Congress may regulate gender-motivated violence, it would be able to regulate murder or any other type of violence since gender-motivated violence ... [is] a subset of all violent crime." $I d$. at 615.

${ }^{266}$ According to the majority, with the VAWA Congress could potentially regulate "family law and other areas of traditional state regulation since the aggregate effect of marriage, divorce, and childrearing on the national economy is undoubtedly significant." $I d$. at 615-16.

${ }^{267} I d$. at 655-66.

${ }^{268}$ Brzonkala v. Virginia Polytechnic Inst. \& State Univ., 169 F.3d 820, 906-08 (4th Cir. 1999) (Motz, dissenting) aff'd sub nom. United States v. Morrison, 529 U.S. 598, 120 S. Ct. 1740, 146 L. Ed. 2 d 658 (2000).

${ }^{269}$ See discussion supra note 225.
} 


\section{Part VII: The Press Did Not Report On The VAWA's Successes Or Its Civil Rights Promise}

Mixed messages about the VAWA civil rights remedy also came from another source: the nation's press. The subject matter of the articles covering the civil rights remedy and the rhetoric used in them suggests that the press, like the judiciary, did not fully embrace the civil rights remedy. This then affected the public's perception of the civil rights remedy, and prevented its symbolic message from taking hold. The press' reporting, which focused mostly on the challenges VAWA claims faced, also likely influenced potential plaintiffs and lawyers and reduced the number of claims filed under the civil rights remedy.

News articles objectively reported some litigation brought under the civil rights remedy. The Brzonkala case received, far and away, the most press coverage. ${ }^{270}$ There are several reasons why this litigation attracted the most media attention. For one, the case was one of the first in which the constitutionality of the civil rights remedy was challenged. ${ }^{271}$ Second, the case involved a well-known university, and two members of its successful football team. ${ }^{272}$ Third, the District Judge in the case was the first to declare the statute unconstitutional, ${ }^{273}$ and this ruling was later affirmed by the only Circuit Court to consider the question. ${ }^{274}$ Fourth, activist groups on both sides of the aisle (NOW LDF and the CIR) were involved in the case at an early stage. ${ }^{275}$ News reports described the case's posture at each stage of the litigation, recounted the facts, and summarized the court's holdings ${ }^{276}$ Given that the district court, and then the Fourth Circuit, held

\footnotetext{
${ }^{270}$ For an extensive overview of the coverage of the Morrison decision, see Russell, supra note 4.

${ }^{271}$ See discussion of the initial constitutional challenges, discussed supra Part V. Brzonkala was the second VAWA case to be filed.

${ }^{272}$ Both the defendants played for the Virginia Tech football team, which, during the 1994-95 season was ranked $17^{\text {th }}$. http://www.collegefootballpoll.com/1994_archive_computer_rankings.html

${ }^{273}$ Brzonkala, 935 F. Supp. 779.

${ }^{274}$ Brzonkala v. Virginia Polytechnic Inst. \& State Univ., 169 F.3d 820, 906-08 (4th Cir. 1999)

${ }^{275}$ Brzonkala, 935 F. Supp. 779.

${ }^{276}$ For a concise summary of the objective press of the Morrison litigation see Russell, supra note 4 at
} 
the statute unconstitutional, ${ }^{277}$ much of this reporting was about the civil rights remedy's inability to withstand judicial scrutiny.

The press did not substantially cover most of the other cases filed under the civil rights remedy. ${ }^{278}$ Only nine of the cases were at all noted in the news. ${ }^{279}$ Some of these cases were only briefly mentioned in local or regional papers. ${ }^{280}$ The cases that did receive coverage fall into two categories: early cases where the constitutionality of the VAWA was challenged and cases involving a high-profile person, institution or event.

The initial cases ruling on the constitutionality of the VAWA were report in the national press. The first case to hold the statute constitutional, a suit by a wife against her former husband in Connecticut, was covered. ${ }^{281}$ The Hartford Courant wrote a piece after the case was filed, and noted that the complaint's facts read "like a gothic novel."282 After the judge's ruling, most major newspapers ran an article about the finding. ${ }^{283}$ These articles noted the facts of the case, (the allegation that the husband treated his wife as a slave, "even forcing her to take care of his mistress' poodle and to pick our clothes for his extramarital affairs" was commonly noted), and

\footnotetext{
${ }^{277}$ Brzonkala v. Virginia Polytechnic Inst. \& State Univ., 169 F.3d 820, 906-07 (4th Cir. 1999) (Motz, dissenting), aff'd sub nom. United States v. Morrison, 529 U.S. 598, 120 S. Ct. 1740, 146 L. Ed. 2 d 658 (2000).

${ }^{278}$ The author searched for the two parties names from each case in the "WestLawNext" News database. If necessary, the results were narrowed by a search for the judge's name, or the phrase "violence against women," or both. I also cross-referenced with LexixNexis' "Major Newspapers" database and GoogleNews Search. The author is in the process of cross-referencing with ProQuest Historical Newspapers.

${ }^{279}$ The only cases for which press was located thus far are: Brzonkala/Morrison, Doe v. Doe, 929 F.Supp 608 (D. Conn. 1996), Seaton v. Seaton, 971 F. Supp 1188 (E.D. Tenn. 1997), Ericson v. Syracuse University, 45 F. Supp 2d 344 (S.D.N.Y 1999), Culberson v. Doan, 65 F.Supp 2d 701 (S.D. Ohio 1999), Doe v. Walker, 193 F.3d 42 (1st Cir. 1999); Mattison v. Click Corp. of Am., Inc., CIV.A. 97-CV-2736, 1998 WL 32597, *2 (E.D. Pa. Jan. 27, 1998); Burns v. Landers, CV 9661671S, 1997 WL 759828 (Conn. Super. Ct. Nov. 21, 1997); Manikhi v. Mass Transit Admn., 733 A. 2d 372 (Md. Ct. Spec. App. 1999).

${ }^{280}$ For example, the Hartford Courant reported on Burns v. Landers, before it was appealed. Jury Finds Man Did Not Injure Wife, Manchester Court News, HARTFORD Courant, Dec. 2, 1995. The Baltimore Sun reported on the disposition of Manikhi v. Mass Transit Admin, after the VAWA claim was dismissed. Laura Cadiz, Court Allows Sex Harassment Suit to Advance, BALT. Sun, Aug. 25, 2000.

${ }^{281}$ Doe v. Doe, 929 F.Supp 608 (D. Conn. 1996).

${ }^{282}$ Mark Pazniokas, Wife Files Suit for 'Gender Violence,' HARTFORd COURAnT, May 14, 1996.

${ }^{283}$ James Barron, Federal Judge Upholds Law on Violence Against Women, N.Y. Times, June 20, 1996, at B4; Jane Hirt, Judge Extends Federal Violence Law to Spouse-Abuse Case, ChiCAGo Tribune, June 20, 1996. Judge Upholds Use of Federal Violence Against Women Act in Wife's Lawsuit, AP ONLINE, June 19, 1996. Court Backs Rights of Abuse Victims, Boston GLOBE, June 20, 1996.
} 
the judge's finding that the VAWA was constitutional. ${ }^{284}$ Another case decided a year later in which the court found the statute constitutional, but did so "quite reluctantly," 285 was also featured. The newspapers typically quoted the judge's “deep discomfort with the law's sweeping nature" and predicted that the VAWA was "widely expected to make its way to the Supreme Court." ${ }^{286}$ The other decisions, which ruled on the constitutionality of the statute and overwhelming found it constitutional, ${ }^{287}$ did not make national news.

The other cases covered by the press involved a compelling high-profile institution or person. Several articles discussed a lawsuit filed against the Syracuse University Tennis Coach. ${ }^{288}$ Two former players filed suit alleging that the coach "was sexually aggressive in giving massages during road trips, and that he walked unannounced into their campus apartments and talked to them frequently about sex."289 The coach also "repeatedly made inappropriate sexual comments aimed at initiating a sexual relations," when these advances were denied he berated the women and hit them with tennis balls. ${ }^{290}$ Importantly, none of the articles reported that the suit was brought under the VAWA, instead they describe it as one for "harassment."291 Additionally, days after the case settled, District Judge Rakoff wrote an opinion solely to put in writing his view that the VAWA was constitutional. ${ }^{292}$ This was not reported.

\footnotetext{
${ }^{284}$ See Hirt, supra note 298.

${ }^{285}$ Seaton v. Seaton, 971 F. Supp 1188 (E.D. Tenn. 1997).

${ }^{286}$ See Nina Bernstein, Judge Upholds Law Making Gender-Motivated Crime a Civil Rights Violation, N.Y. Times, July 10, 1997; Duncan Mansfield, Judge Upholds Federal Law on Violence Against Women, AP ONLINE, July 10, 1997; Women Violence Law Passes U.S. Court Test Civil-Rights Gender Issue May Face Appeal, CHICAGO TRIBUNE, July 10, 1997.

${ }^{287}$ For a discussion of these cases, see supra Part VI.

${ }^{288}$ Tennis-Syracuse: Suit Claims Harassment, N.Y. TIMES, May 15, 1998; Tennis-Tennis Players Settle Lawsuit, N.Y. TIMES, March 27, 1999; Former Players Help Case Against Tennis Coach, AP OnLINE, January 25, $1999 ;$ Al Guart, \$50M Tennis Sex Suit Rocks Syracuse U., NEW YORK Post, May 15, 1998.

${ }^{289}$ Former Players Help Case Against Tennis Coach, AP OnLINE, January 25, 1999

${ }^{290}$ Tennis-Syracuse: Suit Claims Harassment, N.Y. TIMES, May 15, 1998

291 See note 303 supra.

${ }^{292}$ Ericson v. Syracuse University, 45 F. Supp 2d 344 (S.D.N.Y 1999).
} 
Another case that attracted media attention involved a woman who was raped by three men while attending a party at a professional basketball player's home. ${ }^{293}$ The district court originally dismissed this suit but it was re-instated under a theory of supervisory liability by the First Circuit. ${ }^{294}$ The press focused on the professional basketball player's involvement as a host and his potential for liability. ${ }^{295}$ Most of the coverage mentioned that the suit was brought in part under the VAWA, but did not explore the civil rights remedy further. The one article that did, headlined "Woman's Lawsuit Based on Federal Act," was factually inaccurate. It did not contain the word "civil rights." 296 The article wrongfully claimed that the VAWA was amended in 1998 to allow civil suits, and stated that the U.S. Attorney had used the remedy in at least one criminal case, ${ }^{297}$ when in fact the VAWA civil rights remedy can only be used in civil lawsuits. The other cases that received significant media coverage include a suit against a prominent millionaire who was sued in Philadelphia for making his employee a "sex slave," 298 and the suit of the family of a domestic violence victim, whose ex-boyfriend was publically tried and convicted for murder. ${ }^{299}$ This spotty newspaper coverage indicates that the press overwhelmingly focused on the VAWA's constitutional challenges. The media did not publicize cases in which the constitutionality of the statute was upheld, or when plaintiffs had success. The successful plaintiffs that were reported on were mentioned because their story had another compelling hook

\footnotetext{
${ }^{293}$ Doe v. Walker, 193 F.3d 42 (1st Cir. 1999)

${ }^{294} \mathrm{Id}$.

${ }^{295}$ See e.g., Jimmy Golen, Appeals Court Reinstates Suit Against Celtics Star, AP ONLINE, Oct. 6, 1999; Ralph Ranalli, Civil Suit vs. Celts Star Walker Thrown Out; Judge: No Role in Alleged Rape, Boston HeRALD, Dec. 12, 1998.

296 John Ellement, Woman's Lawsuit Based on Federal Act, Boston GLOBE, May 30, 1998.

${ }^{297} \mathrm{Id}$.

${ }^{298}$ See e.g., Became a Sex Slave, Suit Says Millionaire O.C. Bottler Denies Claim, PhILADELPHIA DAILy NeWs, April 23, 1997.

${ }^{299}$ See e.g., Government Backs Suit by Couple Seeking Site of Slain Daughter's Body, CLEVELAND PLAIN DEALER, Sept. 6, 1998.
} 
that was unrelated to the civil rights remedy. The VAWA portions of these articles were underdeveloped, or just plain wrong.

In addition, the writers of editorials and opinion columns debated the VAWA civil rights remedy, and were mixed in their support for it. In particular the idea that gender-violence was a civil rights violation was discussed. Writers of the articles that explored this concept in the most depth tended to be advocates who were involved in the drafting of and lobbying for the civil rights remedy. For example, the Executive Director of the NOW LDF, Kathy Rogers, wrote a letter to the editor that appeared in the Washington Post in November 1997 in which she stated: "rape, domestic violence, and sexual assault, violate women's civil rights." ${ }^{300}$ Then she argued that "[s] urely vindicating the civil rights of more than half our country's citizens is a 'pressing' federal interest that the White House commendably has identified as a cause for national concern and action." ${ }^{301}$ Julie Goldschied, a NOW LDF lawyer who argued Morrison before the Supreme Court, also wrote letters to the editors of various newspapers declaring the value, and legality, of the civil rights remedy. ${ }^{302}$ Attorneys in the New York State Attorney General's office argued in the National Law Journal that the VAWA "is civil rights legislation of the classic sort: motivated, at its core, by documented bias and discrimination." ${ }^{303}$ These articles, and others like them, ${ }^{304}$ achieved what the VAWA advocates had pressed for: sending a symbolic message about violence against women.

Opinion writers who criticized the VAWA civil rights remedy countered this success. Opponents leveled a potent challenge to the civil rights remedy's symbolic goal by suggesting

\footnotetext{
${ }^{300}$ Kathy Rogers, Letter to the Editor, Legislating Against Hate, Wash. Post, Nov. 28, 1997, at 7E. ${ }^{301}$ Id.

${ }^{302}$ See e.g., Julie Goldschied, Letters, Congress Was Within Its Rights to Protect Civil Rights, WASH. TIMES, Aug. 16, 1996 at A20.

${ }^{303}$ Andrew G. Celi, Jr. \& Jennifer K. Brown, VAWA is Valid and Needed, NAT. L. J., Jan 17, 200 at A18.

${ }^{304}$ Kathy Rodgers, Editorial, Ending Violence Against Women, WASH. Post, Apri. 5, 1999 at A16. Insert more articles.
} 
that women's civil rights were not promoted by the civil rights remedy. They claimed that the VAWA actually infringed on civil rights. For example, columnist Cathy Young contested the entire notion that rape and sexual violence against women were gender-motivated, because men and boys were sexually assaulted too, and gay and lesbian couples experienced domestic abuse. ${ }^{305}$ She used this point to argue that rape and sexual assault against women was fundamentally different than "anti-black or anti-Asian violence... because of racial prejudice." 306 A Cornell University professor argued that men were more likely to be the victims of violent crime, and therefore "if anyone needs protection from violence... it is men." ${ }^{307}$ An attorney for Morrison, Curt Levy of CIR made a similar claim. He argued that the rights of accused men "suffer" when the VAWA "single[s] out women as victims and men as predators...the statue ratifies the radical feminist view of men as the oppressor class. ${ }^{{ }^{308}}$ The VAWA's visionary message here met significant resistance.

Together, both types of media coverage had implications for the VAWA. Fundamentally, the press failed to report on most of the VAWA litigation. The media did not provide a nuanced account of the theory underlying the statute in the stories they did recount, and thus did not educate the public about the message the civil rights remedy was intended to send. When the media focused primarily on the cases that found the statute unconstitutional, they overemphasized the statute's failures at the expense of its successes. As a result, lawyers and plaintiffs were likely not educated about the civil rights remedy, or were convinced that it was simply too problematic to be worth bringing a case. The divided editorials were also consequential. They suggest that the message that the civil rights remedy intended to send was

\footnotetext{
${ }^{305}$ Cathy Young, Doing Violence to Equal Protection, DetroIT News, Aug. 8, 1995, at 7E. ${ }^{306} \mathrm{Id}$.

307 Jeremy Rabkin, More Equal Than Others: Has 'Equal Justice' Been Sacrificed to the Feminists?,AM. SPECTATOR, May 1997, at 51.

${ }^{308}$ Curt A. Levey, Feminists Ignore 'Brzonkala' Facts, NAT’L L. J., Feb 7, 2000 at A20.
} 
not fully espoused by the press, and in some instances, it was vociferously refuted. Like the judiciary, the press did not deliver the message advocates of the VAWA had hoped.

\section{Conclusion}

At every step of the way, the VAWA civil rights remedy faced powerful obstacles. The conception of the civil rights remedy made everything that came after an uphill battle. Its radical origins were rooted in the aspirational, but unrealistic, legal thought of feminists. At the moment of its passage, advocates stressed the groundbreaking vision the remedy espoused, but in so doing, obscured crucial questions about how, when, and by whom it would be used. Once in place, the civil rights remedy fared no better. Women's groups who had successfully advocated for the law's passage stood still, rather than instigating a litigation campaign, and only stepped in to triage when the situation begun to fall apart. A handful of motivated and incentivized lawyers brought claims, but their resources were limited and coordination between them non-existent. Opponents quickly challenged these practitioners with a formidable constitutional argument. As the few claims that were brought were litigated, judicial rulings were mixed, and some rejected or severely limited the civil rights law. All the while, the press reported on the VAWA's constitutional troubles, and failed to expound on the message advocates intended the civil rights remedy to send.

This story is a foil to the enormous litigation campaign that followed in the wake of Title VII of the Civil Rights Act of 1964. Title VII was not completely novel. Decades of nondiscrimination theory, ${ }^{309}$ prominently embraced in Brown v. Board of Education, informed the initial formulation of Title VII. These ideas had gained public support, and in the build-up to the passage of the Act, became a focal point of protests like the 1963 March on Washington and

\footnotetext{
${ }^{309}$ See generally Anthony Chen The Fifth Freedom: Jobs, Politics, And Civil Rights in the United States 1941-72 (2009); David Freeman Engstrom, The Lost Origins of American Fair Employment Law: Regulatory Choice and the Making of Modern Civil Rights, 1943-72, 63 STAN. L. R. 1071 (2011).
} 
lunch counter sit-ins. Large public support put mounting pressure on these ideas, and forced them into law. ${ }^{310}$ The theories of MacKinnon and West had no such support.

In part because the Civil Rights Act did not allocate funding like the VAWA, the key purpose of Title VII was to stop discrimination in the workplace, not just send a message that it was a civil rights violation. The link between the lawsuits and the goal was more clearly defined, which prevented the symbolic goal from overshadowing the practical. If injunctions were issued against employers, they would be forced to open their workplaces. If they were ordered to pay back pay to an employee fired discriminatorily, they would be less likely to engage in that behavior again. Title VII was also simply more astutely designed: its enforcement was not left entirely to the private bar, but rather it was done in tandem with the federally appointed and sympathetic Equal Employment Opportunities Commission (EEOC). Also, it explicitly applied to parties with significant financial resources-employers of a designated size. ${ }^{311}$

Following passage of Title VII, the NAACP and the NAACP LDF led a significant charge to immediately bring claims. On the first day the law was valid, they filed 1,000 complaints with the newly opened EEOC. ${ }^{312}$ Their attorneys, a devoted cadre of activists, "serv[ed] as brokers between the grass roots and the state, [and] ... buil[t] up a body of case law in support of economic inclusion." ${ }^{313}$ The director of the LDF, Jack Greenberg, later noted that the Fund, which grew substantially in size during this period and engaged the help of thousands of volunteers, "brought virtually all the cases that gave Title VII law its bite."314

\footnotetext{
${ }^{310}$ For a detailed discussion of the passage of Title VII, see Todd S. Purdum, An IDEA WhOSE TIME HAS Come: Two Presidents, Two PARTies, AND the BAtTle FOR THE Civil Rights ACt OF 1964 (2014).

${ }^{311}$ See 42 U.S.C. $§ 2000$.

${ }^{312}$ JACK GREENBERG, CRUSADERS IN THE COURTS, 444 (2004)

${ }^{313}$ MacLean, supra note 20 at 86.

${ }^{314} I d$. at 85 . (Citing CRUSADERS IN THE COURTS at 443 )
} 
Unlike the few lawyers that brought claims under the VAWA, these attorneys did not face an early constitutional challenge. The public accommodations portion of the Civil Rights Act of 1964, Title II, was challenged almost immediately after the law's passage, but the Supreme Court quickly affirmed that this provision was constitutional, ending all debate on the matter. ${ }^{315}$ Title VII was also not read as narrowly as the civil rights remedy, by either the judiciary adjudicating claims under it or the press reporting on these suits. The explanation for this largely cycles back to the origins of the law — the long campaign and political pressure to pass the Civil Rights Act made its acceptance, and widespread use after passage, far more likely.

This year marks the fiftieth anniversary of the Civil Rights Act of 1964 and the twentieth anniversary of the Violence Against Women Act. Celebrations will mark each milestone. Commemorations of the Civil Rights Act will be widespread, and are likely to focus prominently on Title VII and the change it has achieved. ${ }^{316}$ In contrast, celebrations of the VAWA will be limited to those most ardently interest in women's rights. If the civil rights remedy is discussed, its demise will be lamented and blamed entirely on a conspiratorial conservative Supreme Court. Supporters will suggest that if not for the Rehnquist court, their feminist vision would have been achieved.

This paper is an attempt to press for a deeper, more nuanced dialogue on the anniversary of these important laws. Title VII's success should not just be remembered as an inevitable victory of the Civil Rights movement, but as the subtle and layered syncing of a multitude of factors, which allowed the civil rights legislation to provoke meaningful change. The VAWA civil rights remedy cannot be relegated to the token of an ideological court. Its origins, passage, and short history must be re-examined, because they too, point to the host of forces that must

\footnotetext{
${ }^{315}$ See Katzenbach v. McClung, 379 U.S. 294 (1964); Heart of Atlanta Motel, Inc. v. U.S., 379 U.S. 241 (1964).

${ }^{316}$ See e.g. Purdum, supra note 310; Clay Rise, The Bill of the Century: The EPIC BATtLe FOR THE CiviL RiGHTS ACT (2014).
} 
align for civil rights legislation to work in practice. Once the many dimensions - public and private, conceptual and practical, legislative and judicial, social movement and media- of the VAWA's failure are understood, activists can begin to imagine solutions at every level, and create civil rights legislation that once again produces a veritable revolution. 


\section{Appendix I}

\section{U.S.C $§ 13981$. Civil rights}

\section{(a) Purpose}

Pursuant to the affirmative power of Congress to enact this part under section 5 of the Fourteenth Amendment to the Constitution, as well as under section 8 of Article I of the Constitution, it is the purpose of this part to protect the civil rights of victims of gender motivated violence and to promote public safety, health, and activities affecting interstate commerce by establishing a Federal civil rights cause of action for victims of crimes of violence motivated by gender.

(b) Right to be free from crimes of violence

All persons within the United States shall have the right to be free from crimes of violence motivated by gender (as defined in subsection (d) of this section).

(c) Cause of action

A person (including a person who acts under color of any statute, ordinance, regulation, custom, or usage of any State) who commits a crime of violence motivated by gender and thus deprives another of the right declared in subsection (b) of this section shall be liable to the party injured, in an action for the recovery of compensatory and punitive damages, injunctive and declaratory relief, and such other relief as a court may deem appropriate.

(d) Definitions

For purposes of this section--

(1) the term "crime of violence motivated by gender" means a crime of violence committed because of gender or on the basis of gender, and due, at least in part, to an animus based on the victim's gender; and

(2) the term "crime of violence" means--1

(A) an act or series of acts that would constitute a felony against the person or that would constitute a felony against property if the conduct presents a serious risk of physical injury to another, and that would come within the meaning of State or Federal offenses described in section 16 of Title 18, whether or not those acts have actually resulted in criminal charges, prosecution, or conviction and whether or not those acts were committed in the special maritime, territorial, or prison jurisdiction of the United States; and

(B) includes an act or series of acts that would constitute a felony described in subparagraph (A) but for the relationship between the person who takes such action and the individual against whom such action is taken.

(e) Limitation and procedures

(1) Limitation

Nothing in this section entitles a person to a cause of action under subsection (c) of this section for random acts of violence unrelated to gender or for acts that cannot be demonstrated, by a preponderance of the evidence, to be motivated by gender (within the meaning of subsection (d) of this section).

(2) No prior criminal action

Nothing in this section requires a prior criminal complaint, prosecution, or conviction to 
establish the elements of a cause of action under subsection (c) of this section.

(3) Concurrent jurisdiction

The Federal and State courts shall have concurrent jurisdiction over actions brought pursuant to this part.

(4) Supplemental jurisdiction

Neither section 1367 of Title 28 nor subsection (c) of this section shall be construed, by reason of a claim arising under such subsection, to confer on the courts of the United States jurisdiction over any State law claim seeking the establishment of a divorce, alimony, equitable distribution of marital property, or child custody decree.

(Pub.L. 103-322, Title IV, § 40302, Sept. 13, 1994, 108 Stat. 1941.) 


\section{Appendix II}

Cases in Which the VAWA Was Found Constitutional (12)

Anisimov v. Lake, 982 F.Supp 531 (N.D. Ill. 1997)

Crisonino v. New York City Housing Authority, 985 F. Supp 385 (S.D.N.Y 1997)

Culberson v. Doan, 65 F.Supp 2d 701 (S.D. Ohio 1999)

Doe v. Mercer, 37 F. Supp 2d 64 (D. Mass 1999)

Ericson v. Syracuse University, 45 F. Supp 2d 344 (S.D.N.Y 1999)

Burgess v. Cahall, 88 F.Supp. 2d 319 (D. Del. 2000)

Doe v. Doe, 929 F. Supp 608 (D. Conn. 1996)

Liuu v. Striuli, 36 F. Supp 2d 452 (D R.I. 1999)

Mattison v. Click Corp. of Am., Inc., CIV.A. 97-CV-2736, 1998 WL 32597 (E.D. Pa. Jan. 27

1998)

Seaton v. Seaton, 971 F. Supp 1188 (E.D. Tenn. 1997)

Timm v. Delong - 59 F. Supp 2d 944 (D. Neb. 1998)

Ziegler v. Ziegler, 28 F. Supp 2d 601 (E.D. Wash. 1998)

\section{Cases in Which the VAWA Was Struck Down as Unconstitutional (3)}

Bergeron v. Bergeron, 48 F.Supp. 2d 628 (M.D. La. 1999)

Santiago v. Alonso, 96 F.Supp 2d 58 (D. P.R. 2000)

United States v. Morrison, 529 U.S. 598 (2000)

\section{Cases in Which Plaintiffs Won on the Merits (10)}

Avila-Franco v. Worrell, 1998 U.S. Dist. LEXIS 12129 (D.D.C. 1998)

B.F., by her Parent \& Natural Guardian, K.F. v. Smith, C8-97-1468, 1998 WL 101348 Blair v. All Stars Sports Cabaret, 87 F. Supp. 2d 1133 (D. Colo. 2000)

Doe v. Hartz, 970 F. Supp 1375 (N.D. Iowa 1997)

Doe v. Walker, 193 F.3d 42 (1st Cir. 1999)

Jugmohan v. Zola 98 CIV. 1509 (DAB), 2000 WL 222186 (S.D.N.Y. Feb. 25, 2000) Kuhn v. Kuhn, 98 C 2395, 1998 WL 673629 (N.D. Ill. Sept. 16, 1998)

McCann v. Byron L. Rosquist, D.C., P.C., 998 F. Supp. 1246 (D. Utah 1998)

Peddle v. Sawyer, 64 F. Supp. 2d 12 (D. Conn. 1999)

Thorpe v. Virginia State Univ., 6 F. Supp. 2d 507 (E.D. Va. 1998)

\section{Cases in Which Plaintiffs Lost on the Merits (27)}

Bell v. Cuyahoga Cmt. Coll., 129 Ohio App. 3d 461, 717 N.E. 1189 (1998)

Braden v. Piggly Wiggly, 4 F. Supp 2d 1357 (M.D. Ala. 1998)

Bridges v. City of Dallas, CIV. 3:98-CV-0090-H, 1998 WL 320286 (N.D. Tex. June 8, 1998)

Burns v. Landers, No. CV 9661671S, 1997 WL 759828 (Conn. Super. Ct. Nov. 21, 1997)

Chase v. Genesis Consol. Servs., Inc., 1999 WL 1327395 (D.N.H 1999)

Comardelle v Hernandez, 26 F. Supp 2d 897 (E.D. La. 1998)

Dill v. Oslick, CIV. A. 97-6753, 1999 WL 50867 (E.D. Pa. July 19, 1999)

Doe v. Abbott Laboratories, 892 F. Supp 811 (E.D. La. 1995)

Dolin on Behalf of N.D. v. West, 22 F. Supp 2d 1343 (M.D. Fla. 1998)

Evert v. Swick, 2000 MT 191, 300 Mont. 4278 P.3d 773 (1998)

Glendora v. Pinkerton Security and Detective Services, 25 F.Supp.2d 447 (S.D.N.Y. 1998) 
Grace v. Nissan, 76 F. Supp. 2d 1083 (D. Or. 1999)

Grimm v. Shoyer, 35 F. Supp 2d 966 (E.D. Ky. 1999)

Gross v. Weber, 186 F. 3d 1089 ( $8^{\text {th }}$ Cir. 1999)

Harris v. Franklin-Williamson Human Services, Inc., 97 F.Supp 2d 892 (S.D. Ill. 2000) Harris v.

Zappan, CIV A 97-4957, 1999 WL 360203 (E.D.Pa May 28, 1999)

Henderson v. Hartland Press, Inc., 65 F. Supp 2d 991 (N.D. Iowa 1999)

LeBlanc v. Lee, CIV. A. 97-1811, 1999 WL 670976 (E.D. La. Aug. 24, 1999)

Manikhi v. Mass Transit Admin., 360 Md. 333, 758 A.2d 95 (2000)

Palazzolo v. Ruggiano, 993 F. Supp 45 (D. R.I. 1998)

Sherman v. Helms, 80 F. Supp. 2d 1365 (M.D. Ga. 2000)

Schwenk v. Hartford, 204 F.3d 1187 (9th Cir.2000)

Thomasson v. United States, 99-3165-JTM, 1999 WL 690098 (D. Kan. Aug. 23, 1999) Truong

v. Smith, 28 F. Supp. 2d 626 (D. Colo. 1998)

Wesley v. Don Stein Buick, 42 F. Supp. 2d 1192 (D. Kas. 1999)

Whitaker v. Mercer County, 65 F.Supp.2d 230 (D. N.J. 1999)

Wilson v. Diocese of New York of Episcopal Church, 96 Civ. 2400 (JKG), 1998 WL 82921

(S.D.N.Y Feb. 26, 1998)

\section{Cases in Which a VAWA Claim Was Mentioned but the Merits or Constitutionality Was}

Not Addressed (7)

Balas v. Ruzzo, 703 So.2d 1076 (Fla. Dist. Ct. App. 1997)

Doe v. Old Rochester Reg'l Sch. Dist., 56 F. Supp. 2d 114 (D. Mass. 1999)

Fahey-Hosey v. Capano, 98C-06-299 SCD, 1999 WL 743985 (Del. Super. Aug. 31, 1999)

Finley v. Higbee Co., 1 F. Supp.2d 701 (N.D. Ohio 1997)

Newton v. Coca-Cola Bottling Company, 958 F. Supp 248 (W.D. N.C. 1997)

Reich v. Reich, 657 N.Y.S.2d 671 (App. Div. 1997)

Williams v. Board of County Commissioner et al, 192 F. R. D 698 (D. Kan. 2000) 